\title{
TRACE FOSSILS FROM THE PERMIAN TERESINA FORMATION AT CERRO CAVEIRAS (S BRAZIL)
}

\author{
JOÃO HENRIQUE DOBLER LIMA \& RENATA GUIMARÃES NETTO \\ Programa de Pós-Graduação em Geologia, UNISINOS, Av. Unisinos, 950, 93022-000, São Leopoldo RS, Brasil. \\ jhdl_bio@hotmail.com,nettorg@unisinos.br
}

\begin{abstract}
The ichnofauna of the Teresina Formation from the Cerro Caveiras (Dom Pedrito, Rio Grande do Sul State, South Brazil) is revised in this paper. Bergaueria isp., Cochlichnus cf. anguineus, Cruziana problematica, cf. Diplocraterion isp., Diplopodichnus biformis, Helminthopsis isp., Lockeia siliquaria, Multina arcuata isp. nov., Oldhamia isp., Palaeophycus striatus, P. tubularis, Phymatoderma burkei, Planolites beverleyensis, P. montanus, Teichichnus isp., and Thalassinoides isp. were recorded. Isopodichnus problematicus, Helminthopsis tenuis and Unarites isp., previously described in these deposits are now described as Cruziana problematica, indeterminate molluscan trail, and Multina arcuata isp. nov., respectively. The ichnofauna is composed chiefly of horizontal, simple shallow burrows, with a predominance of feeding structures. Resting, dwelling and crawling structures also occur, as well as indeterminate tiny grazing trails, but are less frequent. Ichnodiversity and intensity of bioturbation are usually low, and P. montanus is the commonest ichnotaxon. The main characteristics of the ichnofauna suggest a marine benthic fauna stressed by salinity fluctuations and resulting in an impoverished Cruziana ichnofacies. The absence of vertical burrows and the common occurrences of monospecific assemblages of Planolites indicate extreme stress events, probably due to the establishment of freshwater conditions. Further studies focused on the ichnological signatures of these deposits will provide more detailed information to improve the current paleoecologic and paleoenvironmental interpretations of the Teresina Formation deposits.
\end{abstract}

Key words: ichnology, Teresina Formation, Cerro Caveiras, Permian, Paraná Basin, South Brazil.

RESUMO - A icnofauna dos depósitos da Formação Teresina aflorantes no Cerro Caveiras (Dom Pedrito, RS) é aqui revisada. Foram registrados os icnotáxons Bergaueria isp., Cochlichnus cf. anguineus, Cruziana problematica, cf. Diplocraterion isp., Diplopodichnus biformis, Helminthopsis isp., Lockeia siliquaria, Multina arcuata isp. nov., Oldhamia isp., Palaeophycus striatus, P. tubularis, Phymatoderma burkei, Planolites beverleyensis, P. montanus, Teichichnus isp. e Thalassinoides isp. Isopodichnus problematicus, Helminthopsis tenuis e Unarites isp., previamente descritos nestes depósitos, são aqui identificados como Cruziana problematica, pista indeterminada de molusco e Multina arcuata isp. nov., respectivamente. Escavações simples, rasas, horizontalizadas, com domínio de estruturas de alimentação caracterizam a icnofauna estudada. Estruturas de repouso, moradia, e deslocamento, além de diminutas pistas de pastagem indeterminadas ocorrem subordinadas. A icnodiversidade e o índice de bioturbação são baixos, em geral, e P. montanus é o icnotáxon mais comum. As características gerais da icnofauna sugerem uma fauna marinha bentônica estressada por flutuações de salinidade e permitem reconhecer uma assembleia de Icnofácies Cruziana empobrecida. A ausência de escavações verticais e a ocorrência comum de assembléias monoespecíficas de Planolites indica estresse acentuado, decorrente do estabelecimento de condições de água doce. Estudos futuros focados no reconhecimento e na análise das assinaturas icnológicas da Formação Teresina no Cerro Caveiras permitirão um melhor entendimento paleoecológico e paleomabiental da sucessão.

Palavras-chave: icnologia, Formação Teresina, Cerro Caveiras, Permiano, bacia do Paraná.

\section{INTRODUCTION}

Studies on the ichnofauna from the Upper Permian deposits of the Paraná Basin in Rio Grande do Sul State (RS), south of Brazil, were focused on the top of the Teresina Formation (formerly assumed as the Serrinha Member of the Rio do Rasto Formation) in the southwest part of the RS (Netto, 1988, 1992). Two ichnocoenoses were recognized, one restricted to the region of Tiaraju (ichnocoenosis A), containing the ichnogenera Planolites, Teichichnus and Thalassinoides, and the other recorded at Cerro Caveiras (ichnocoenosis B), containing Cochlichnus, Flabellichnus, Helminthopsis, Isopodichnus,
Planolites, Thalassinoides and Unarites (Netto, 1988, 1992). This trace fossil assemblage was interpreted by Netto (1992) as representative of a low ichnodiverse Cruziana ichnofacies produced in a shallow epicontinental marine setting with tidal influence. Netto (1992) also considered the hypothesis that this trace fossil assemblage had developed in a "mixed environment", due to the regressive pattern of the sedimentary succession and the presence of continental deposits overlying the analyzed strata.

Since then, the knowledge on the ichnology of freshwater (e.g. Buatois \& Mángano, 1993, 1995, 2004, 2007; Bromley, 1996; Gibert et al., 2000; Buatois et al., 2002) and brackish-water (e.g. 
Pemberton \& Wightman, 1992; Bann \& Fielding, 2004; Buatois et al., 2005; MacEachern et al., 2005, 2007) deposits considerably increased, providing new information about trace fossil distribution in shallow marine and coastal environments stressed by salinity fluctuations and/or reduced oxygenation levels, such as estuaries and deltas (e.g. Bromley, 1996; Netto, 2001; Buatois et al., 2002, 2005; Martin, 2004; MacEachern et al., 2007; Savrda, 2007). Also, the proposition of well defined criteria for morphologic description of the trace fossils (Bromley, 1996; Bertling et al., 2006) facilitated the ichnotaxonomic assignation and led to several studies revising many ichnotaxa, including some of those originally described by Netto $(1988,1992)$.

This considerable advance on the ichnology paradigms brought with it new parameters, which favor a more accurate analysis of the paleoecology of these deposits and the paleoenvironment in which they were formed. However, it depends on a detailed ichnotaxonomic study. Thus, the aim of this paper is to revise the ichnofauna of the Upper Permian deposits exposed at the Cerro Caveiras locality, in order to provide detailed information to future studies on the paleoecology and paleoenvironment of the Teresina Formation.

\section{MATERIAL AND METHODS}

The ichnotaxonomic revision that is the basis of this study was carried out using the ichnofossil specimens from Cerro Caveiras (Dom Pedrito, RS, Figure 1), originally described by Netto $(1988,1992)$ and housed at the trace fossils collection of the Laboratório da História da Vida e da Terra (LaViGea) from
UNISINOS, under the numbers EO-009, ULVG-8315 (formerly EO-070), U-1573, U-1575, U-1576, U-1640, U-1641, U-1643, U-1652 to U-1659, U-1662 to U-1679, U-1682 to U-1690, U-1692, U-1693, U-1695 to U-1698, U-1700 to U-1703, U-1705, U-1707 to U-1712, U-1714 to U-1719, U-1721 and U-1723 to U-1728. Specimens observed in the field were also studied.

New specimens were collected during this analysis and were catalogued in the LaViGea under the numbers ULVG-7802 to ULVG-7806 and ULVG-8314.

\section{GEOLOGY OF THE STUDY AREA}

The trace fossil assemblage studied herein came from the Cerro Caveiras outcrop, situated at the northwest of Dom Pedrito City (RS) (UTM 0706867E/6580577N to 0707057E/6581133N, strip 21J, Southern Hemisphere; Figure 1). The sedimentary rocks exposed at this outcrop are Permian in age and compose the upper deposits of the Teresina Formation (Permian, Paraná Basin).

The Teresina Formation is part of a $3^{\text {rd }}$ order sedimentary sequence that characterizes the regressive succession developed at the end of the Permian in the Paraná Basin (Milani, 1997; Milani et al., 2007), representing sedimentation in a shallow marine environment (Figueiredo Filho, 1972; Schneider et al., 1974; Gama Jr., 1979; Rohn, 1989; Lavina, 1991; Klein et al., 1999). Lima (2010) recognized five sedimentary facies in the studied succession (Figure 2): (i) mudstone; (ii) fine-grained heterolithic; (iii) sandstone with climbing ripple lamination; (iv) sandstone with trough cross-stratification, and (v) sandstone with hummocky cross-stratification (HCS) and swaley cross-stratification (SCS).

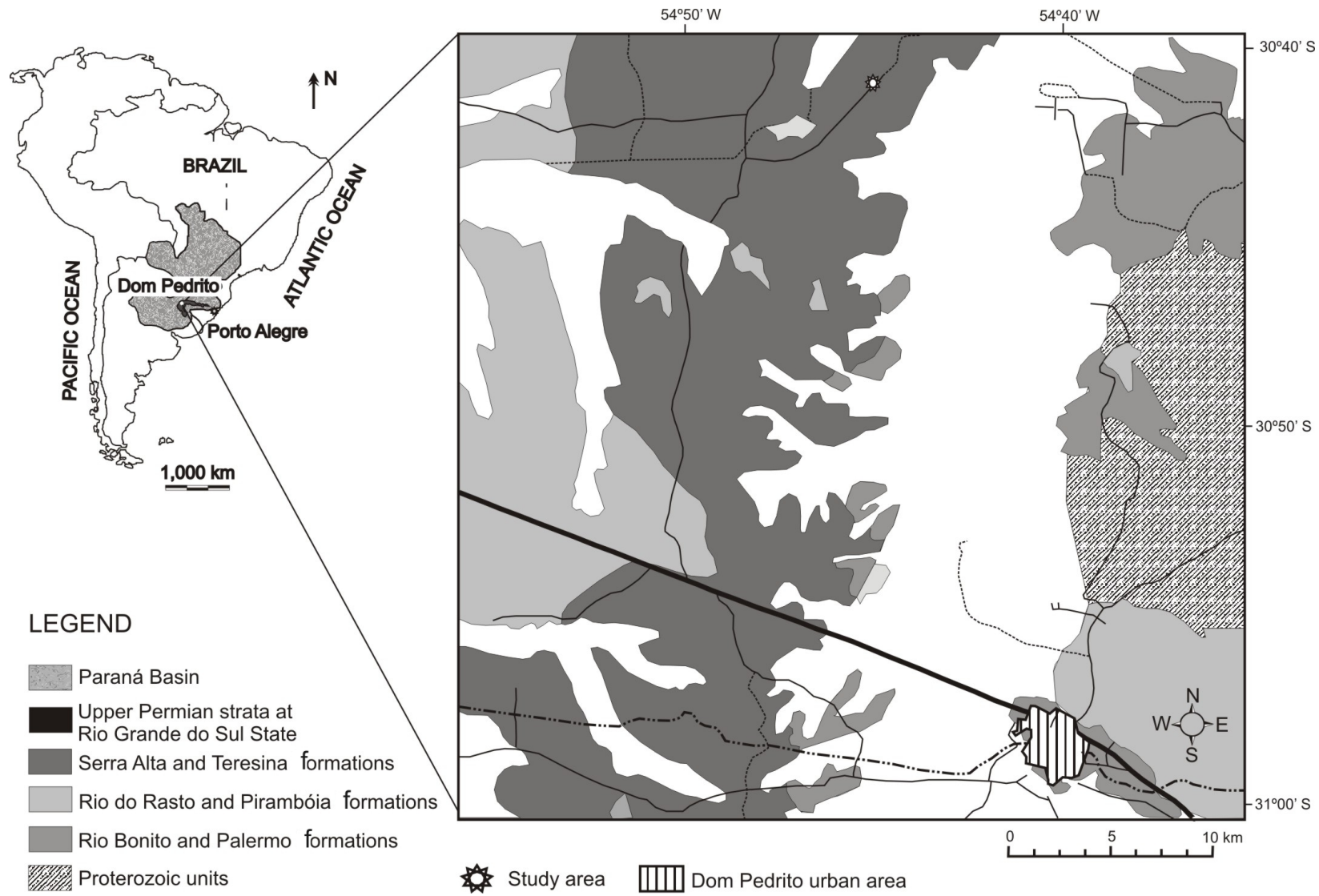

Figure 1. Geologic map with location of the study area (modified from Wildner et al., 2006). 

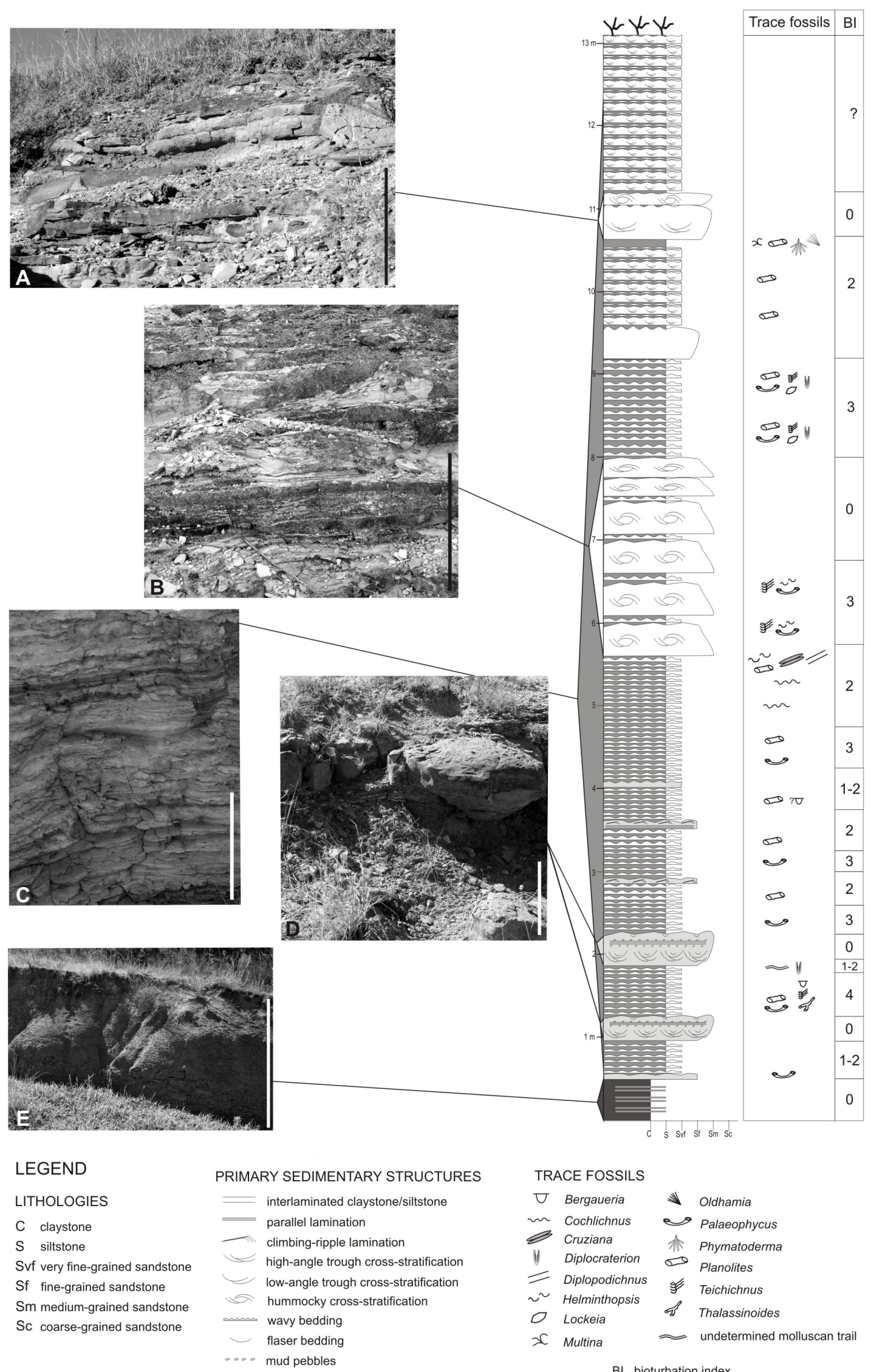

BI bioturbation index

Figure 2. Schematic profile and sedimentary facies of the Teresina Formation sedimentary succession exposed at Cerro Caveiras. A, sandstone with trough cross-stratification facies; $\mathbf{B}$, sandstone with HCS and SCS facies; C, fine-grained heterolithic facies; $\mathbf{D}$, sandstone with climbing ripple lamination facies; E, mudstone facies. Scale bars $=10 \mathrm{~cm}(\mathrm{C})$ and $50 \mathrm{~cm}(\mathrm{~A}-\mathrm{C}, \mathrm{E})$. Bioturbation index follow the Taylor and Goldring (1993) scale. 
These sedimentary facies revealed the predominance of wave action and allowed inferring deposition in a lower shoreface-offshore transition zone affected by unidirectional currents, maybe generated by a prograding delta (Lima, 2010). They form stacked coarsening- and thickening-upward cycles and characterize the deposits observed in the upper part of the Teresina Formation. These deposits are overlaid by retrogradational/agradational cycles (Figure 2).

\section{ICHNOTAXONOMY}

\author{
Ichnogenus Bergaueria Prantl, 1945 \\ Bergaueria isp.
}

(Figure 3A)

Analyzed material. One specimen in sample U-1641, and another observed in the outcrop.

Description. Short, plug-shaped, vertical burrow, with an elliptical base and a central depression at the basal end. Burrow borders are smooth, with very discrete lining. Ornaments are absent. Burrow fill is similar to that of the host rock. Minimum diameter of the basal end is $17.3 \mathrm{~mm}$, maximum is 19.25 $\mathrm{mm}$; maximum height preserved is $4.75 \mathrm{~mm}$. Preservation in positive hyporelief.

Discussion. Bergaueria differs from the ichnogenera Conichnus and Dolopichnus by its general geometry and from Conostichnus by the absence of an apical disc and ornamentation on the borders of the burrow (Pemberton et al., 1988). According to these authors, the diagnostic criteria for ichnospecific differentiation in Bergaueria are the thickness of the burrow lining and the presence and morphology of the ornamentation at the basal end. The specimen collected at Cerro Caveiras is apparently incomplete or suffered strong weathering process, having no remaining diagnostic characters that would allow the inclusion of this specimen in any known ichnospecies.

Bergaueria is interpreted as the dwelling or temporary reclusion structure of anthozoans (anemones), which is passively filled by sand after the animal death or the burrow abandonment (e.g. Alpert, 1973; Häntzschel, 1975; Pemberton et al., 1988; Ekdale \& Lamond, 2003), being preserved mostly as protuberances at the base of sandy beds. Bergaueria occurs from the Precambrian up to the Recent, and albeit being a common component of marine ichnocoenoses, it is also recorded in marginal marine successions, suggesting some resistance of their producer to slight oscillations in water salinity (e.g. Dam, 1990; Crimes \& Crossley, 1991; Buatois \& Mángano, 1993; Buatois et al., 2009).

\section{Ichnogenus Cochlichnus Hitchcock, 1858 \\ Cochlichnus cf. anguineus Hitchcock, 1858}

(Figures 3B-C)

Analyzed material. Four specimens in samples U-1652 and ULVG-7806.

Description. Shallow, horizontal, unbranched burrow, whose trajectory is composed of one or more regular sinuous meanders. Burrow without lining, showing active compacted fill. Average burrow diameter is $1 \mathrm{~mm}$. The wavelength and the amplitude of the sinuous meanders vary between the specimens, but remain stable between the curves of the same specimen. Preserved in full relief.

Discussion. The description and identification of Cochlichnus followed the same approach of Balistieri et al. (2002), which included burrows and sinusoidal trails within this ichnogenus when the establishment of a safe distinction between them was not possible. Nonetheless, and spite of the slight irregularity of the meanders, the trajectory markedly sinusoidal of the structures described herein suggest a preservational variation of C. anguineus. Annulations or lateral marks that differentiate C. anguineus from respectively $C$. annulatus and C. antarticus (Buatois et al., 1997) were not observed.

Nematodes, annelids, cyclostomates and fly larvae had been suggested as Cochlichnus tracemaker (Chamberlain, 1975; Buatois \& Mángano, 1993; Głuszek, 1995; Gibert et al., 2000; Uchman et al., 2009). However, Diptera are not present in the fossil record before the Upper Triassic (Mángano et al., 1996). Grazing, feeding, locomotion, and predation are the main ethologic behaviors represented by Cochlichnus (Eagar et al., 1985; Dam, 1990; Netto, 1992; Buatois \& Mángano, 1993; Głuszek, 1995; Buatois et al., 1997; Sarkar et al., 2009), being recorded in marine, marginal-marine and continental subaquatic environments, including lacustrine (e.g. Buatois \& Mángano, 1993, 1995; Gibert et al., 2000; Netto et al., 2009; Uchman et al., 2009), deltaic (Eagar et al., 1985; Melchor et al., 2003) and fluvial deposits (see compilation by Buatois \& Mángano, 2007).

\section{Ichnogenus Cruziana d Orbigny, 1842 Cruziana problematica Schindewolf, 1921} (Figure 3D)

1988 Isopodichnus problematicus Netto, p. 40, fig. 15,16. 1992 Isopodichnus problematicus Netto, p. 71, fig. 5C.

Analyzed material. Two specimens in samples ULVG-7806 and U1573/I006 and specimens observed in the outcrop.

Description. Shallow, narrow bilobed intrastratal structure, formed by two parallel to subparallel asymmetric ridges separated by a median groove. The ridges are ornamented by discrete scratch marks arranged obliquely to the median groove. Trail trajectory slightly curved. Width of the complete structure varies from 3.75 to $4.21 \mathrm{~mm}$ and of the median groove is $1 \mathrm{~mm}$ in average. Preservation in positive hyporelief. Discussion. Superficial to relatively deep intrastratal furrow, showing two contiguous, parallel ridges that form two lobes (in positive hyporelief) ornamented by scratch marks arranged in an oblique way are characteristics exclusive of the ichnogenus Cruziana (Keighley \& Pickerill, 1996). The presence of discrete scratch marks and of uniformly shallow, narrow lobes is diagnostic of C. problematica (e.g. Keighley \& Pickerill, 1996; Schlirf et al., 2001; Balistieri et al., 2002; Lermen, 2006).

Cruziana is generally interpreted as produced by the locomotion activity (sometimes allied with feeding) of 
arthropods, chiefly trilobites. The only ichnoespecies not attributed to trilobites is $C$. problematica, which results from the displacement of isopod and notostracan crustaceans and, possibly, myriapods (e.g. Bromley \& Asgaard, 1979; Pollard, 1985; Keighley \& Pickerill, 1996; Schlirf et al., 2001). In Upper Paleozoic rocks, C. problematica has been recorded mainly in non-marine deposits (Bromley \& Asgaard, 1979; Gradzinski \& Uchman, 1994; Schlirf et al., 2001; Balistieri et al., 2002; Lermen, 2006).

\section{Ichnogenus Diplocraterion Torell, 1870 cf. Diplocraterion isp.}

(Figures 3A, E)

Analyzed material. Five specimens in samples U-1641, U-1663, 1665 and U-1676.

Description. Vertical, cylindrical, linked shafts suggesting a U-shaped burrow with spreiten. Shafts show slightly lined borders without ornamentation. Burrow fill is lithologycally similar to the host rock. Shaft diameters range from $3.50 \mathrm{~mm}$ to $5.07 \mathrm{~mm}$, and distance between the two shafts of the same structure ranges from $2.15 \mathrm{~mm}$ to $5.35 \mathrm{~mm}$. Preservation in positive hyporelief.

Discussion. The samples containing cf. Diplocraterion isp. collected at Cerro Caveiras allow assessing only the morphology of the structure visible in horizontal section, which made impossible its identification at the ichnospecies level. For the same reason, it was not possible to characterize the spreiten of the studied specimens as retrusive or protrusive, leaving doubt about the activity by which the producer had left this record. The lack of visualization of the vertical components of the structure confers to these specimens a preservation similar to Arthraria (Fillion \& Pickerill, 1984).

In general, Diplocraterion is interpreted as the permanent dwelling of suspension or detritus feeders, but also represents equilibrium activity of the tracemaker in response to high or frequent sedimentation and/or erosion events (e.g. Turner et al., 1981; Bromley, 1996; Savrda \& Nanson, 2003; Seilacher, 2007). Although very often recorded in marine deposits, Diplocraterion also occurs associated with in brackish-water ichnofaunas through all the Phanerozoic, as summarized by Buatois et al. (2005), as well as in tide-dominated deltaic deposits (e.g. McIlroy, 2004, 2007; Chakraborty \& Bhattacharya, 2005). Similarly, other studies suggest that the producers of Diplocraterion possessed reasonable tolerance to stressful environments where the variation of hydrodynamic energy, oxygenation and salinity is high (e.g. Ager \& Wallace, 1970; Leszczyński et al., 1996; Goldring et al., 2005). The specimens collected at Cerro Caveiras are preserved at the base of fine sandstone beds, associated with Bergaueria, Planolites, Palaeophycus and Lockeia.

Ichnogenus Diplopodichnus Braddy, 1947

Diplopodichnus biformis Braddy, 1947

(Figure 3C)

Analyzed material. Two specimens in sample ULVG-7806.
Description. Trackways formed by two continuous, smooth and parallel ridges, separated by a median groove, with width greater than that of the ridges. The trajectory is rectilinear to slightly curved, and no ornamentation is observed. Total width of the trackway ranges from 3.10 to $4.21 \mathrm{~mm}$ and width of the median groove varies between $1.70 \mathrm{~mm}$ and $2 \mathrm{~mm}$. Preserved in positive hyporelief.

Discussion. Based on the diagnoses proposed by Keighley \& Pickerill (1996) and Buatois et al. (1998), the abovementioned characteristics are diagnostic of the ichnogenus Diplopodichnus, where D. biformis is its ichnospecies-type.

According to Keighley \& Pickerill (1996), Diplopodichnus is the intermediate preservation mode of the ichnogenera Cruziana (deep furrows) and Diplichnites (epistratal trackways). The suggestion that Diplopodichnus and Cruziana would result from distinct modes of displacement of the same producer is supported at Cerro Caveiras, where these two ichnogenera occur associated in beds that also contain wrinkle structures, induced by the action of microbial mats in subaquatic or moist substrate (Noffke et al., 2001). Microbial mats serve as a source of food for detritus feeders and algae grazers and also favor the preservation of trackways, shallow furrows and undertracks of epigenic organisms (Seilacher, 2008).

The origin of Diplopodichnus biformis has been largely associated with the displacement of diplopods (e.g. Johnson et al., 1994; Keighley \& Pickerill, 1996; Balistieri et al., 2002, 2003; Lermen, 2006) or of myriapod-like aquatic animals (e.g. Buatois et al., 1998) in softgrounds. In Paleozoic rocks, $D$. biformis has been widely recorded in deposits suggestive of very shallow conditions and probable temporary exposure of the substrates associated with lacustrine margins and supratidal marginal-marine environments (Aceñolaza \& Buatois, 1993; Buatois et al., 1998; Nogueira \& Netto, 2001a,b; Balistieri et al., 2002, 2003; Lermen, 2006; Netto et al., 2009).

\section{Ichnogenus Helminthopsis (Wetzel \& Bromley, 1996) Helminthopsis isp.}

(Figures 3B, F)

Analyzed material. Three specimens in samples U-1652 and ULVG-7802, and specimens observed in the field.

Description. Horizontal, cylindrical burrows, whose trajectory forms irregular meanders. The amplitude of the meanders is variable between specimens and along the same specimen. The occurrence of U-shaped fragments of meanders is common. Branching or overlapping is not observed. Smooth borders, without lining. The burrow fill is similar to that of the host rock. Preservation in positive epirelief or positive hyporelief.

Discussion. Simple, not branched, elongated, cylindrical burrows with open irregular meanders characterize the ichnogenus Helminthopsis (Wetzel \& Bromley, 1996). According to the authors, the differentiation of Helminthopsis ichnospecies should be based on the geometric pattern of the trace fossil, but Han \& Pickerill (1995) considered that ornamentation can also be a diagnostic criterion. Some specimens observed at Cerro 
Caveiras fit in the diagnosis of Uchman (1998) for H. abeli, due to its horseshoe shape. However, the other specimens show meanders of much higher amplitude, and none of the forms observed is preserved with sufficient quality for reliable identification at the ichnospecies level.

Helminthopsis is a facies-crossing ichnotaxon, interpreted as feeding or grazing burrow produced by a vermiform endobiont detritus feeder, probably a polychaete (e.g. Dam, 1990; Hann \& Pickerill, 1995; Uchman, 1998). Mángano et al. (1996) pointed to insect larvae as producers of Helminthopsis in lacustrine Permian deposits from Argentina. This ichnogenus has been recorded from Cambrian to Holocene in marine (e.g. Dam, 1990; Uchman, 1998; Uchman et al., 2005; Sarkar et al., 2009), deltaic (e.g. Bann \& Fielding, 2004; Gani et al., 2007; Buatois et al., 2008) and non-marine settings (e.g. Buatois \& Mángano, 1995, 2007; Mángano et al., 1996; Buatois et al., 1997; Krapovickas et al., 2009).

\section{Ichnogenus Lockeia James, 1879 \\ Lockeia siliquaria James, 1879}

(Figures 3G; 5A-B)

\begin{abstract}
Analyzed material. Twenty-one specimens in samples EO-009, U-1665, U-1675, U-1678, U-1683, U-1692, U-1696, U-1705, U-1712, U-1715 and U-1728.
\end{abstract}

Description. Elongated, almond-shaped protuberance with smooth borders. The majority of the specimens shows a median ridge, evidencing the bilateral symmetry of the structure. Fill is lithologycally similar to the host rock. All specimens occur isolated. Average width of the structures is $3.71 \mathrm{~mm}$, ranging from $2.21 \mathrm{~mm}$ to $6.11 \mathrm{~mm}$. Average length is $8.97 \mathrm{~mm}$, ranging from $4.89 \mathrm{~mm}$ to $15.24 \mathrm{~mm}$. Preservation in positive hyporelief.

Discussion. The morphology of the described specimens fits perfectly on the diagnosis of the ichnospecies Lockeia siliquaria proposed by Schlirf et al. (2001). Otherwise, the characteristic ornamentation of $L$. ornata and the linear arrangement of $L$. cunctator and Ptycoplasma (former $L$. serialis, see Uchman et al., 2011) are absent. In spite of tiny specimens of Lockeia occur associated with conchostracan and ostracod (Bromley \& Asgaard, 1979; Maples \& Suttner, 1990), the interpretation of these burrows as resulting from the temporary resting of bivalve mollusks is recurrent in the literature (e.g. Seilacher \& Seilacher, 1994; Bromley, 1996; Mángano et al., 1998; Ekdale \& Bromley, 2001; Seilacher, 2007). Some of the specimens of $L$. siliquaria studied by Mángano et al. (1998) preserved in association with vertical to inclined shafts, suggest stable domiciles instead of resting structures. The life position and vertical mobility of the producer indicate that they would have been suspension/filter feeders able to excavate and inhabit shallow and deep tiers within the substrate.

The aforementioned authors also point out that Lockeia siliquaria could represent an escape structure, motivated by changes in environmental conditions. Ekdale \& Bromley (2001) reported the occurrence of L. siliquaria,
Protovirgularia dichotoma and Lophoctenium isp. composing a single biogenic structure (later named as Hillichnus lobosensis by Bromley et al., 2003) in Pennsylvanian deposits of the U.S.A. and interpreted each ichnotaxon as a reflection of a different behavioral pattern (rest, displacement and feeding, respectively) of a bivalve. The assemblage dominated by $L$. siliquaria described by Gibert \& Ekdale (2002, Middle Jurassic, U.S.A.) is composed of structures that show extremely shallow penetration within the substrate (in the order of millimeters), a characteristic that was attributed to substrate dysoxia.

The specimens collected at Cerro Caveiras are not associated with trails, or vertical shafts and are present at the base of sandstone layers with thickness of the order of tens of centimeters, supporting the idea of resting behavior. The records of Lockeia are limited to permanently subaquatic environments with different levels of salinity, being more common in marine, deltaic and estuarine deposits (e.g. Balistieri et al., 2002; Uchman et al., 2004; Buatois et al., 2005, 2009; Goldring et al., 2005; Coates \& MacEachern, 2007).

\section{Ichnogenus Multina Orłowski, 1968 Multina arcuata isp. nov.}

(Figures 4A-C)

1988 Unarites sp. Netto, p. 44-45, figs. 28, 29. 1992 Unarites sp. Netto, p. 73-74, figs. 5I, 5J.

Etymology. From arcuate, bent or curved like a bow. Diagnosis. Multina with curved tunnels and tight network pattern, showing rare true branches and high density of overlapping.

Analyzed material. A total of 234 specimens in samples U-1575, U-1576 (holotype), U-1643, U-1654, U-1655, U-1656 (paratype) and ULVG-7805, and specimens observed in the field.

Description. Irregular, curved cylindrical tunnels displayed horizontally on the bedding planes, whose trajectory forms open meanders. Burrow overlapping and constrictions are frequent and true branching, rare. Burrow margins delimited but without lining and compacted active burrow fill. Burrows are preserved in clusters in muddy beds, composing a tightly interlaced pattern of varied density, and occurring isolated in sandy beds. Burrow diameter ranges from $0.58 \mathrm{~mm}$ to 3.33 $\mathrm{mm}$. Preservation in positive hyporelief.

Discussion. The analyzed specimens were described by Netto (1988, 1992) as Unarites Macsotay (1967). However, in the original diagnosis of Unarites and its type-ichnospecies ( $U$. suleki), overlapping - a marked characteristic in the specimens from Cerro Caveiras - are not observed. U. suleki was assumed to be a synonym of Megagrapton submontanum by Uchman (1998), while other authors observed similarities between Multina magna (type-ichnospecies of the ichnogenus Multina) and Megagrapton submontanum (Orłowski \& Żilińska, 1996; Buatois et al., 2009), but did not put them in synonym. 

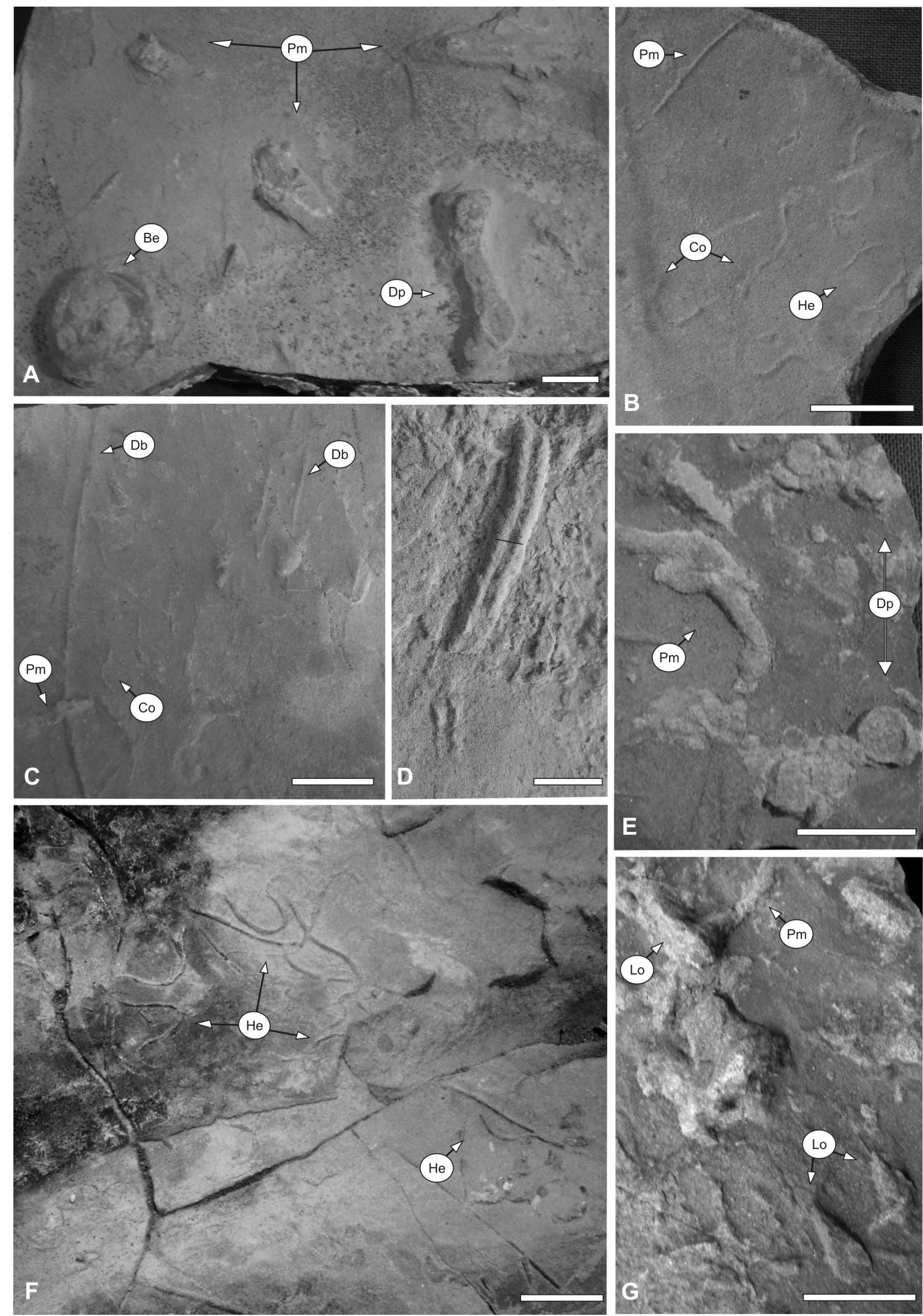

Figure 3. Ichnofauna from the Teresina Formation at Cerro Caveiras. A, Bergaueria isp., cf. Diplocraterion isp. and Planolites montanus (U1641). B, Cochlichnus cf. anguineus, Helminthopsis isp. and P. montanus (U-1652). C, Cochlichnus cf. anguineus, Diplopodichnus biformis and P. montanus (ULVG-7806). D, Cruziana problematica (U-1573). E, cf. Diplocraterion isp. and P. montanus (U-1663). F, Helminthopsis isp. (specimens in outcrop). G, Lockeia siliquaria and P. montanus (U-1683). Abbreviations: Be, Bergaueria; Cp, Cruziana; Co, Cochlichnus; Db, Diplopodichnus; Dp, Diplocraterion; He, Helminthopsis; Lo, Lockeia; Pm, Planolites montanus. Scale bars = $10 \mathrm{~mm}$. 
The ichnogenus Multina shows horizontal burrows of small size that form irregular networks with passive or active fill, allowing the display of appendages and overlapping within the same network (Uchman, 2001). Tunnels of Multina magna can be straight and form irregular polygons up to $5 \mathrm{~cm}$ wide, crossing each other in successive bifurcations (Orłowski \& Żilińska, 1996). Multina minima shows tunnels of smaller diameter, never more than $5 \mathrm{~mm}$, and a pattern of very irregular network, forming elongated undulations and overlapping, whose intensity can obliterate the original reticular structure (Uchman, 2001). The specimens from Cerro Caveiras show more pronounced bending tunnels and a more irregular network pattern than M. magna and M. minima. Also, the scarcity of true branches and the high density of overlapping forming tight clusters are not observed in the known ichnospecies.

Multina is interpreted as a burrow produced by vermiform organisms for the purpose of feeding (Buatois et al., 2009). The specimens from Cerro Caveiras are preferentially preserved as clusters in muddy patches deposited in the concavities between the ripple crests. This particular mode of preservation suggests that the tight pattern of the tunnel network is a response of the concentration of grazing activity in muddy zones, where food might be more abundant.

Multina has been described as post-depositional structures in fine to very fine sandy marine turbiditic deposits, with occurrence from the Middle Cambrian up to the Eocene (Uchman, 2001; Rodriguez-Tovar et al., 2010). At Cerro Caveiras, all the specimens of Multina occur in the same beds bearing Oldhamia isp. and Phymatoderma burkei.

\section{Ichnogenus Oldhamia Forbes, 1849 \\ Oldhamia isp.}

(Figure 4E)

1988 ?Oldhamia flabellata Netto, p. 41, figs. 17, 18. 1992 Flabellichnus nowatzkii Netto, p. 70, fig. 5B.

Analyzed material. One specimen in sample ULVG-8315. Description. Discontinuous, horizontal, flattened, straight to slightly curved probes that diverge from a common point culminating in a single fan-shaped structure. Fifteen tunnels are identified, with borders lacking lining. Overlappings and branches are not observed. Spacing between the burrows has variable size and the diameter of the probes ranges from 0.88 $\mathrm{mm}$ to $2.33 \mathrm{~mm}$. Preserved as positive hyporelief.

Discussion. This specimen was originally identified as ?Oldhamia flabellata by Netto (1988). This assignment was later reviewed by Netto (1992), who re-named it Flabellichnus nowatzkii, considering that the tunnels were more straight and the angles formed by the fan-like structure were smaller than those generally observed in Oldhamia specimens. The preferential record of Oldhamia in Lower to Middle Cambrian rocks also played a role in this redefinition.

The ichnogeneric name Flabellichnus (type-ichnospecies F. lewinnskii, Lower Jurassic of Poland) had been previously erected by Karaszewski (1971) to characterize inflorescence- shaped imprints, consisting of several spindle-shaped 'petals' that rapidly narrow and taper. Flabellichnus was classified by Häntzschel (1975) as an unrecognizable "genus", due to the lacking of sufficient data for an interpretation. Pieńkowski (2008) reviewed the original material, concluding that it would form an incomplete dinosaur footprint and considered the ichnogenus Flabellichnus as invalid, based on standard ichnotaxonomic criteria suggested by Bertling et al. (2006).

Oldhamia shows horizontal and narrow probes, diverging from a common point and results in structures whose morphology varies between flabellate, radial or dendrite shapes, produced by vermiform organisms prospecting under biomats in search of food (e.g. Lindholm \& Casey, 1990; Hofmann et al., 1994; Buatois \& Mángano, 2003; Seilacher et al., 2005; Seilacher, 2007). While most occurrences of Oldhamia are associated with Cambrian deposits, changes of the behavior program developed by its producers have emerged throughout the Paleozoic, probably in response to changes in feeding strategy, as noted in Ordovician, Carboniferous and Permian records (Seilacher, 2003, 2007; Seilacher et al., 2005; MacNaughton, 2007).

The general morphology of the Oldhamia specimen found in Cerro Caveiras shares some diagnostic characters with $O$. antiqua and $O$. flabellata. However, the fan-like structure does not show neither the typical palm leaf arrangement and the firework morphology that are common in O. antiqua, or the tendency to hug the previous probes, common in $O$. flabellata (Seilacher et al., 2005). Fanning probes organized in a less regular mode characterize $O$. fimbriata, the youngest ichnospecies, recorded in Lower Carboniferous to Permian rocks (Seilacher, 2007). The more rectilinear probes and the narrowness of the fan-like structure observed in the Cerro Caveiras specimen resemble the O. fimbriata morphology, but the lack of detailed characterization in the literature does not allow a safe assignation to this ichnospecies.

Oldhamia occurs, almost exclusively, in deep-sea deposits, where the slow sedimentation allows the formation of microbial mats (Seilacher, 2003, 2007; Seilacher et al., 2005; MacNaughton, 2007). At Cerro Caveiras outcrop, the sample identified as Oldhamia isp. was collected in the same fine to medium sandstone bed in which Phymatoderma burkei and Multina arcuata isp. nov., both suggestive of a deeper marine environment, also occur.

\section{Ichnogenus Palaeophycus Hall, 1847 \\ Palaeophycus tubularis Hall, 1847}

(Figure 5B)

Analyzed material. Twenty-two specimens in samples U-1640, U-1641, U-1665, U-1676, U-1679, U-1682, U-1684, U-1689, U-1690, U-1693, U-1695, U-1715 and U-1728 and specimens observed in the field.

Description. Straight to slightly curved cylindrical to subcylindrical burrows, parallel or slightly inclined to bedding. True branching not observed, only intersections. Burrow margin with discrete lining and without ornamentation. Burrow fill composed of sediment identical to that of the 
host rock. Burrow diameter varying within the same sample, being $4.55 \mathrm{~mm}$ in average. Preservation in positive hyporelief. Discussion. The presence of lining and passive fill are the main characteristics that differentiate the ichnogenera Palaeophycus and Planolites (Pemberton \& Frey, 1982; Keighley \& Pickerill, 1995), while the pattern of ornamentation of the burrow wall is the diagnostic criterion for Palaeophycus ichnospecific assignation. The type-ichnospecies $P$. tubularis as well as $P$. heberti lack wall ornamentation, the latter exhibiting a consistently thicker lining than P. tubularis (Frey \& Howard, 1985), not observed in the specimens from Cerro Caveiras.

Palaeophycus is interpreted as a temporary or permanent dwelling structure of a suspension feeder or predator, which is passively filled by the sediment transported by the currents or collapse after abandonement of the structure. This ichnogenus was recorded from the Precambrian up to the Holocene, being common in both marine and freshwater environments (e.g. Buatois \& Mángano, 1993, 2002; Gradzinski \& Uchman, 1994; Scott et al., 2009).
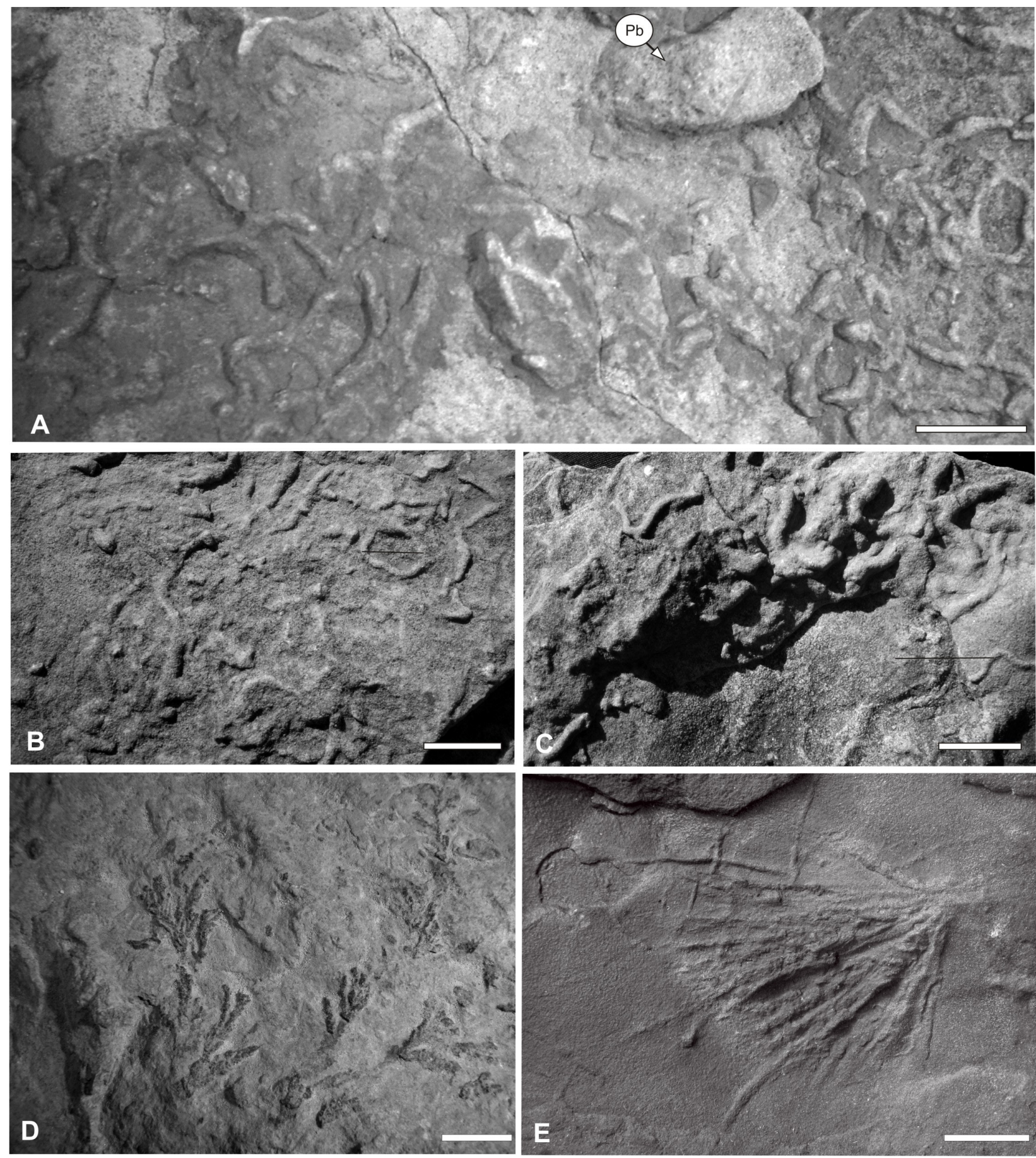

Figure 4. Ichnofauna from the Teresina Formation at Cerro Caveiras. A-C, Multina arcuata isp. nov.: A, general view of the holotype (U-1576); B, detailed view of the holotype; C, detailed view of the paratype (U-1656). D, Phymatoderma burkei (ULVG-8314). E, Oldhamia isp. (ULVG8315). Scale bars $=10 \mathrm{~mm}$. 
Palaeophycus striatus Hall, 1852

(Figure 5F)

Analyzed material. Three specimens, in samples U-1641, U-1664 and U-1712.

Description. Subcylindrical to flattened burrows of slightly curved trajectory, whose extremities plunge into the substrate. Burrow margins lined and ornamented by longitudinal parallel grooves, whose degree of preservation varies among the specimens. Burrow fill is composed of sediment identical to that of the surrounding matrix. Average burrow diameter is 4.79 $\mathrm{mm}$, with a minimum diameter of $1.71 \mathrm{~mm}$ and a maximum diameter of $6.28 \mathrm{~mm}$. Preservation in positive hyporelief.

Discussion. Palaeophycus striatus differs from the other ichnospecies of Palaeophycus by its ornamentation formed by parallel and continuous grooves (Pemberton \& Frey, 1982). According to Maples \& Suttner (1990), preservation of the grooves of $P$. striatus depends on the composition and softness of the substrate, being better preserved in finegrained sediments. However, Buatois et al. (1997) emphasize that the presence of grooves on the borders of $P$. striatus suggests a relatively firmness of the substrate, perhaps in a stage of transition between softground and firmground. From this point of view, Melchor et al. (2003) concluded that the presence of $P$. striatus in sandstones of distributary channels of a lacustrine delta, in Argentina, suggests colonization of partially dehydrated substrate. Although non-exclusive, the recording of $P$. striatus in non-marine deposits is recurrent, especially in a fluvial or lacustrine context (e.g. Keighley \& Pickerill, 1997, 2003; Melchor et al., 2003; Goldring et al., 2005; Buatois \& Mángano, 2007).

\section{Icnogenus Phymatoderma Brongniart, 1849 \\ Phymatoderma burkei Miller, 1991}

(Figure 4D)

Analyzed material. Two specimens in sample ULVG-8314. Description. Burrow system consisting of horizontal, occasionally discontinuous, straight to slightly curved tunnels, with cylindrical section. The tunnels are parallel to the bedding, protruding branches of first, and less frequently, second order, generating dendrite-shaped structures. The two sides of each axis are always asymmetrical. Overlapping is not observed and the angles of branching are variable but not exceeding $45^{\circ}$. Tunnel bundles are formed in specimens with the lowest branching angles. Burrow fill is darker than the host rock and presents few small pellets, oriented parallel to the axis of each tunnel. Burrow margins have no lining and tunnel diameters are around $1 \mathrm{~mm}$. Preservation in positive hyporelief.

Discussion. In spite of Seilacher (2007) highlighted that Phymatoderma differs from Chondrites mainly by the poor definition of burrow contours, Fu (1991) reviewed the fucoids ichnotaxonomy, pointing out that the icnogenus Phymatoderma characterizes a burrow system composed of pustule-like-structures, whose numerous tunnels are filled with transverse arranged pellets, showing a more irregular and denser branching than Chondrites. Miller \&
Aalto (1998) also mentioned other diagnostic morphologies of Phymatoderma, like the subhorizontal orientation of the overall system and the overlapping tunnels. The specimens collected in Cerro Caveiras have visible pellets only in some parts of the galeries, as described in the specimens studied by Miller \& Vokes (1998) and Uchman (1999). Although a pelleted fill is a diagnostic characteristic of Phymatoderma, pellets are highly subject to preservational variations and its observation can be obliterated (Uchman, 1999). Based on the general morphology of the complete structure, Miller (2011) divided the five known ichnospecies of Phymatoderma in three different morphological groups: palmate (P. penicillum and $P$. alcicorne), digitate ( $P$. melvillensis and $P$. granulata) and intermediate (P. burkei). The specimens analyzed herein can be included in the intermediate morphological group. Also, the branching pattern of the structure forms feather-like structures that are different in angle and curvature at each side of the median axis. These characteristics allow including the specimens analyzed in $P$. burkei.

Phymatoderma is considered a burrow system produced by deposit-feeders or sediment-feeders (Fu, 1991; Uchman, 1999; Seilacher, 2007). Phymatoderma is restricted to deposits that reflect deep glaciomarine and deep marine settings, being always produced at the best well-oxygenated substrate levels (Fu, 1991; Miller \& Vokes, 1998; Uchman, 1999; Leszczyński, 2004; Uchman \& Gaździcki, 2010; Miller, 2011). At Cerro Caveiras outcrop, P. burkei occur at the soles of fine to medium-grained sandstone beds bearing also Multina arcuata and Oldhamia isp.

\author{
Ichnogenus Planolites Nicholson, 1873 \\ Planolites montanus Richter, 1937 \\ (Figures 3A-D, F; 5A-B, F)
}

Analyzed material. A total of 173 specimens from samples U-1640, U-1641, U-1652, U-1653, U-1656, U-1658, U-1659, U-1662 to U-1676, U-1678, U-1683 to U-1690, U-1692, U-1693, $\mathrm{U}-1695$ to $\mathrm{U}-1698, \mathrm{U}-1700$ to $\mathrm{U}-1703, \mathrm{U}-1707$ to $\mathrm{U}-1712$, U-1714 to U-1719, U-1721, U-1723 to U-1728, ULVG-7803 and ULVG-7806 and specimens observed in the field.

Description. Horizontal or slightly inclined, rectilinear to slightly curved burrows of flattened to cylindrical section. No branching is observed and overlapping is rare. Burrow with smooth margins, without lining. Burrow fill differs from the host rock by having coarser grains and, apparently, being devoided of organic matter. Average burrow diameter $3.2 \mathrm{~mm}$, the smallest measuring $1.18 \mathrm{~mm}$ and the biggest $7.41 \mathrm{~mm}$. Preservation in positive hyporelief.

Discussion. This is the most abundant ichnospecies within the ichnofauna of the study area. Morphologic variations between the specimens are identifiable, such as differences in the amplitude of burrow curvature (when present) and in the diameter of the sections. Pemberton \& Frey (1982) define size, curvature and annulations as taxonomic keys to differentiate Planolites ichnospecies. Although the size and curvature of the burrow are generally secondary criteria in the description of trace fossils, most of the Planolites specimens 
found in Cerro Caveiras show a markedly sinuous morphology and burrow diameter never exceeding $5 \mathrm{~mm}$, two major characteristics of P. montanus (Pemberton \& Frey, 1982).

Planolites is a facies-crossing structure interpreted as temporary feeding burrows, produced by a non-selective, endobiont detritus feeder (e.g. Häntzschel, 1975; Pemberton \& Frey, 1982; Frey \& Howard, 1985; Keighley \& Pickerill, 1995; Uchman, 1995). Arthropods are also considered as possible producers of Planolites in non-marine environments (Buatois \& Mángano, 1993). This ichnogenus has been recorded in deposits of the Precambrian to Pleistocene age, produced in almost all sedimentary settings (e.g. Frey et al., 1990; Netto, 1992; Buatois \& Mángano, 1993; Buatois et al., 2002, 2005; Uchman et al., 2005; Carmona et al., 2009; Scott et al., 2009).

\section{Planolites beverleyensis Billings, 1862}

(Figures 4A; 5C)

Analyzed material. Ten specimens in samples U-1576, U-1653, U-1657, U-1677, U-1678, U-1692, U-1703, 1718, U-1726 and U-1727.

Description. Horizontal, straight to slightly curved burrows, slightly flattened. Branching or overlapping are not observed. Burrow margins are smooth and without lining. Burrow fill is different in color and granulometry from that which composes the surrounding matrix. Average burrow diameter is $11.3 \mathrm{~mm}$. Preservation in positive hyporelief.

Discussion. The usually wider burrow diameter, up to $8 \mathrm{~mm}$, and the preferentially straight or slightly curved pattern are the main characteristics of Planolites beverleyensis (Pemberton \& Frey, 1982). Absence of annulations and grooves in the analyzed specimens excludes the possibility to include them in $P$. annularius and P. terranovae, respectively (Buatois \& Mángano, 1993).

Average diameter of the specimens from Cerro Caveiras is equivalent to that reported in the literature for specimens of this ichnospecies (Pemberton \& Frey, 1982; Frey \& Howard, 1985; Buatois \& Mángano, 1993). They reflect feeding activity and were produced in the same settings as Planolites montanus, as both are preserved in the same beds.

\section{Ichnogenus Teichichnus Seilacher, 1955 Teichichnus isp. \\ (Figure 5E)}

Analyzed material. Two specimens in samples U-1712 and ULVG-7804 and specimens observed in the field.

Description. Horizontal, concave tile-shaped, unbranched, flattened burrows forming vertical spreite. Burrow margins showing a discrete sinuosity along the burrow and tiles apparently are separated each other by a muddy film. Burrow fill similar to the host rock and burrow course slightly curved. Average burrow diameter is $9 \mathrm{~mm}$. Preservation in positive hyporelief.

Discussion. The lack of clear diagnostic features difficult the assignation of the specimens found in Cerro Caveiras to any of the known Teichichnus ichnospecies. The specimens are observed preferentially in bedding view, therefore most of the details of the spreiten morphology are not visible. However, the presence of a muddy film preserved between the tiles that compose the burrow spreiten suggests that the producer had been a soft-body organism.

Besides crustaceans, vermiform organisms, especially annelids, have been pointed out as possible producers of Teichichnus (e.g. Seilacher, 1964; Dam, 1990; Bland \& Goldring, 1995). Although usually recorded in fully oxygenated substrates, Teichichnus also occurs in substrates with evidence of stressful conditions, such as variations in energy and salinity fluctuations (e.g. Savrda \& Nanson, 2003; Gingras et al., 2007). In this case, specimens are generally smaller and with diminutive and flattened spreiten than those produced in non-stressed environments (Buatois et al., 2005; Pemberton et al., 2001). Teichichnus was identified in rocks whose maximum granulometry does not surpass that of medium sand and whose age varies from the Lower Cambrian to the Recent (e.g. Häntzschel, 1975; Stanton \& Dodd, 1984; Crimes et al., 1992; Corner \& Fjalstadt, 1993). At the studied area, the specimens of Teichichnus isp. occur in heterolithic fine-grained sandstone and mudstone beds intercalated with fine- to medium-grained sandstone showing wavy bedding, swaley ripple and hummocky cross-stratification.

\section{Ichnogenus Thalassinoides Ehrenberg, 1944 Thalassinoides isp.}

(Figure 5A)

Analyzed material. One specimen in sample EO-009. Description. Horizontally oriented, cylindrical burrow, showing Y-shaped branches. The tunnels are straight, with lined margins, and devoided of ornamentation. Burrow fill is passive and similar to the host rock and diameter ranging from $5.21 \mathrm{~mm}$ to $8.25 \mathrm{~mm}$ throughout the specimen, reaching its highest value at the bifurcation zones. Preservation in positive hyporelief.

Discussion. The morphologic characteristics of the studied specimen suggest a pattern usually associated with Thalassinoides suevicus (Rieth, 1932), especially with regard to the horizontal orientation, the width of the burrow at the point of Y-shaped bifurcation, and the smooth borders, suggesting lineation (e.g. Frey \& Howard, 1985; Kim et al., 2002). However, only a single specimen was collected from the Cerro Caveiras, whose preservation limits the observation of all diagnostic features of T. suevicus, as well as of the other ichnospecies of Thalassinoides discussed in the literature (Ekdale, 1992; Myrow, 1995; Rodríguez-Tovar et al., 2008).

Crustaceans, especially decapods, have been indicated as the principal producers of Thalassinoides, in order to construct a shelter and a place to gather food (e.g. Pemberton et al., 1984; Ekdale, 1992; Myrow, 1995; Buatois et al., 2002; Rodríguez-Tovar \& Uchman, 2006). Records of Thalassinoides are common from the Cambrian to the Holocene, despite the scarcity of crustacean body fossils of Paleozoic age. This aspect led some authors to attribute Paleozoic Thalassinoides to some soft-body animals (Myrow, 1995; Bromley, 1996; Ekdale \& Bromley, 2003; Carmona 
et al., 2004). The occurrence of Thalassinoides, although typical of marine environments, is common in marginal marine settings, since the trace makers support variations in bathymetry, salinity and, consistency of the substrate, which can vary from softground to firmground (Ekdale, 1992; Kim et al., 2002; Pemberton et al., 2004; Buatois et al., 2005; Gingras et al., 2007).
Indeterminate molluscan trail

(Figure 5D)

1988 Helminthopsis tenuis Netto, p. 40.

1992 Helminthopsis tenuis Netto, p. 71.

Analyzed material. One specimen in sample U-1651.
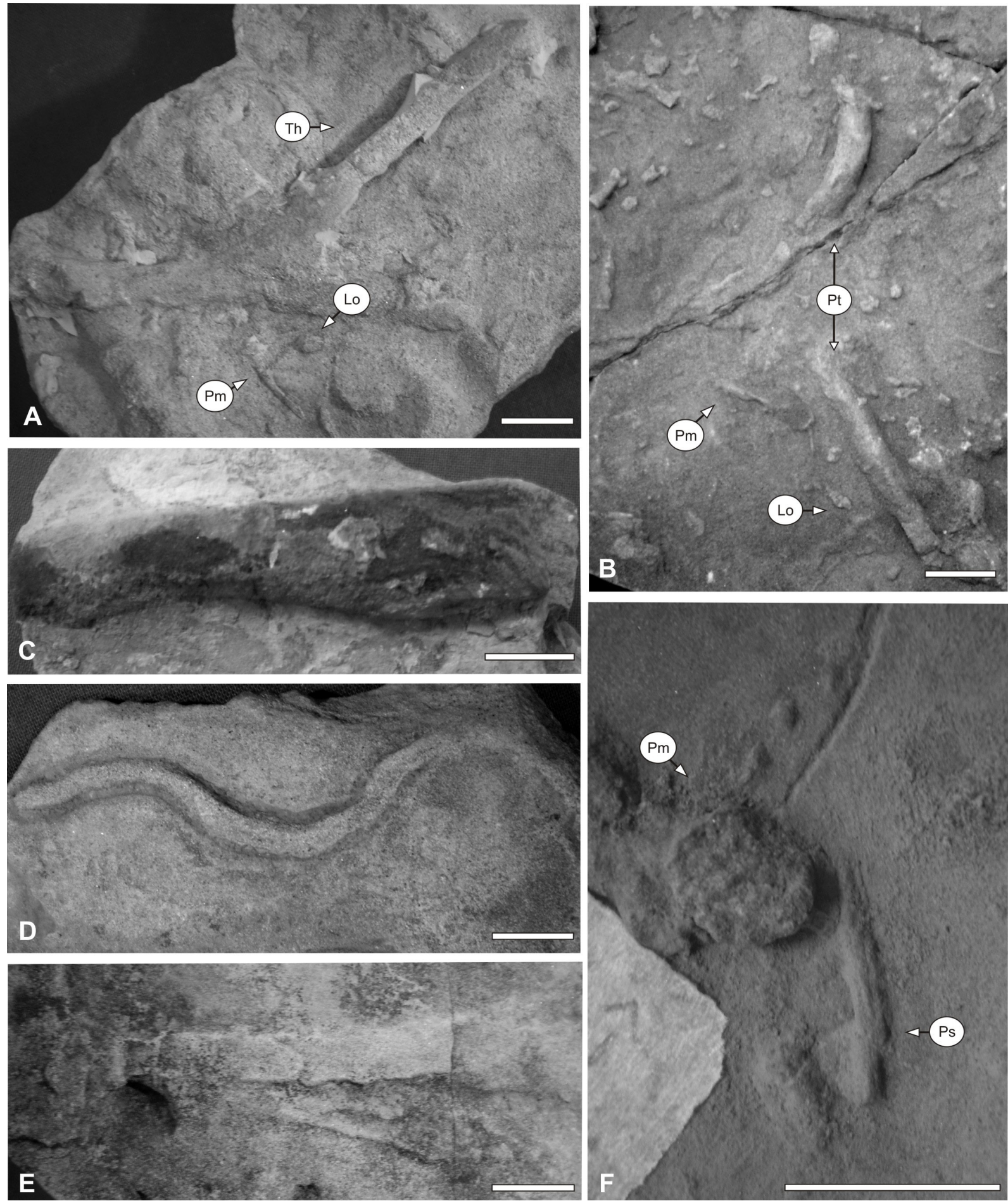

Figure 5. Ichnofauna from the Teresina Formation at Cerro Caveiras. A, Thalassinoides isp., Lockeia siliquaria and Planolites montanus (E-009). B Palaeophycus tubularis, P. montanus, L. siliquaria, and indeterminate grazing trails (U1665). C, Planolites beverleyensis (U-1692). D, indeterminate molluscan trail (U-1651). E, Teichichnus isp. (ULVG-7804). F, Palaephycus striatus and Planolites montanus (U-1664). Abbreviations: Lo, Lockeia; Pm, Planolites montanus; Pt, Palaeophycus tubularis; Ps, P. striatus; Th, Thalassinoides isp. Scale bars $=10 \mathrm{~mm}$. 
Description. Trilobed structure composed of a subcylindrical to flattened ridge, which is divided longitudinally by a delicate median groove and two shallow, parallel sulci, locally discontinuous. The trace fossil trajectory is slightly to markedly undulating. The ridge fill is compacted and lithologycally similar to the host rock. The three lobes are devoid of ornamentation. Width of the sulci varies from 1.3 $\mathrm{mm}$ to $2.4 \mathrm{~mm}$, and the diameter of the ridge is $3.8 \mathrm{~mm}$. Preservation in positive hyporelief.

Discussion. This specimen was originally described and classified by Netto (1992) as Helminthopsis tenuis. However, its trilobed morphology is evident, a feature absent in Helminthopsis. Moreover, Helminthopsis is interpreted as a feeding or grazing burrow (Hann \& Pickerill, 1995; Wetzel \& Bromley, 1996; Uchman, 1998). The presence of a ridge filled by sand from the layer overlying the sample layer in the specimen from Cerro Caveiras, and the existence of sulci parallel to the ridges resulting from the lateral displacement of the sediment during the locomotion of the animal, suggest a trail rather than a burrow.

Trilobed structures with flattened ridges have been associated with molluscan locomotion trails. However, the existence of a single specimen and the lacking of detailed morphological features did not permit a safe assignation to any defined ichnotaxa.

\section{FINAL CONSIDERATIONS}

The ichnofauna of the Teresina Formation preserved at Cerro Caveiras is dominated by shallow and simple burrows, horizontally oriented, and produced at the interface between the sandy and muddy beds. Feeding burrows are the dominant structures, followed by resting, dwelling and locomotion structures, and small indeterminate grazing trails (Figure 5B). Bifurcated burrows or structures with spreite, which suggest a more complex behavioral pattern, are rare. Burrow sizes are compatible with the average sizes recorded in the descriptions of the ichnotaxa that served as the comparative basis of this study (see references in the discussion of each ichnotaxa). Abundance and diversity of bioturbation are low, being Planolites montanus the dominant ichnotaxon, exhibiting a uniform distribution throughout the succession.

The composition of the ichnofauna and the associated sedimentary facies indicate colonization in a subaquatic environment, with the majority of the ichnogenera recorded in shallow marine settings (e.g. Häntzschel, 1975; Pemberton \& Frey, 1982; Schlirf et al., 2001; Sarkar et al., 2009). Simple horizontal burrows are considered temporary feeding structures of detritus feeders (e.g. Pemberton \& Frey, 1982; Frey \& Howard, 1985; Keighley \& Pickerill, 1995), indicating that nutrients were concentrated into the substrate. Absence of structures with reinforced walls suggests a substrate with a soft consistency but relatively stable sediments (softground) and the scarcity of spreite burrows reinforces the hypothesis of a moderate to low hydrodynamic energy, below the wave base (e.g. Frey et al., 1990; Pemberton et al., 1992; Bromley, 1996; Buatois et al., 2002). A particular suite composed of Multina arcuata isp. nov., Phymatoderma burkei, and Oldhamia isp. and preserved at the soles of the sandstone beds that compose the sandstone with trough cross-stratification facies suggests also deposition in deeper marine settings.

As noted by Netto $(1988,1992)$, the general characteristics of the ichnoassemblage of the Teresina Formation at Cerro Caveiras refer to the Cruziana ichnofacies. However, the significantly low ichnodiversity (if compared to typical occurrences of the archetypal Cruziana ichnofacies), the low index of bioturbation and the dominance of simple feeding structures suggest a benthic fauna stressed by fluctuations in salinity (e.g. Beynon et al., 1988; Pemberton \& Whightman, 1992; Bann \& Fielding, 2004; Buatois et al., 2005, 2007; MacEachern et al., 2007; Carmona et al., 2009). The virtual absence of vertical burrows and the common occurrence of monospecific colonization of Planolites, a common suite in non-marine environments, suggest that such fluctuation would be extreme, leading to the establishment of freshwater conditions and to the maintenance of these conditions by long periods (e.g. Bann \& Fielding, 2004; Melchor, 2004; MacEachern et al., 2005; Rossetti \& Netto, 2006; Gani et al., 2007; Buatois et al., 2008; Carmona et al., 2009).

Further studies focusing the integrated analysis of the ichnofauna and the sedimentology of the Teresina Formation at Cerro Caveiras will allow interpret better these ichnological signatures, favoring a better understanding of the paleoecology and paleoenvironments represented by these deposits.

\section{ACKNOWLEDGMENTS}

The authors are grateful to CNPq for the assistance awarded to RGN (479457/2007-7 and 303041/2007-2) to carry out this study, and to CAPES, for the PROSUP fellowship granted to JHDL. A.F. Stranz, for preparing the location map of the study area, to E.L.C. Lavina and F.M.W. Tognoli, for discussions on sedimentology and stratigraphy are also thanked, as well as N. Carmona and A. Uchman, who helped to improve the original manuscript with their critical review. This work is a contribution to Simposio Latinoamericano de Icnología/Latin American Symposium on Ichnology - SLIC 2010.

\section{REFERENCES}

Aceñolaza, F.G. \& Buatois, L.A. 1993. Nonmarine perigondwanic trace fossils from the Paleozoic of Argentina. Ichnos, 2:183-201. doi.org/10.1080/10420949309380092

Ager, D.V. \& Wallace, P. 1970. The distribution and significance of trace fossils in the uppermost Jurassic rocks of the Boulonnais, Northern France. In: T.P. Crimes \& J.C. Harper (eds.) Trace fossils, Geological Journal, Special Issue 3, p. 359-376.

Alpert, S.P. 1973. Bergaueria Prantl (Cambrian and Ordovician), a probable actinian trace fossil. Journal of Paleontology, 47:919-924.

Balistieri, P.; Netto, R.G. \& Lavina, E.L.C. 2002. Ichnofauna from the Upper Carboniferous-Lower Permian rhythmites from Mafra, Santa Catarina State, Brazil: Ichnotaxonomy. Revista Brasileira de Paleontologia, 4:13-26.

Balistieri, P.; Netto, R.G. \& Lavina, E.L.C. 2003. Icnofauna de ritmitos do topo da Formação Mafra (Permo-Carbonífero da Bacia do Paraná) em Rio Negro, Estado do Paraná (PR), 
Brasil. Publicación Especial de la Asociación Paleontológica Argentina, 9:131-139.

Bann, K.L. \& Fielding, C.R. 2004. An integrated ichnological and sedimentological comparison of non-deltaic shoreface and subaqueous delta deposits in Permian reservoir units of Australia. In: D. McIlroy (ed.) The application of ichnology to palaeoenvironmental and stratigraphic analysis, The Geological Society of London, Special Publication 228, p. 273-310.

Bertling, M.; Braddy, S.J.; Bromley, R.G.; Demathieu, G.R.; Genise, J.; Mikulas, R.; Nielsen, J.K.; Nielsen, K.S.S.; Rindsberg, A.K.; Schlirf, M. \& Uchman,A. 2006. Names for trace fossils: an uniform approach. Lethaia, 39:265-286. doi.org/10.1080/00241160600787890

Bland, B.H. \& Goldring, R. 1995. Teichichnus Seilacher 1955 and other trace fossils (Cambrian?) from the Charnian of Central England. Neues Jahrbuch für Geologie und Paläonologie, Abhandlungen, 195:5-23.

Bromley, R.G. 1996. Trace fossils - biology, taphonomy and applications. $2^{\mathrm{a}}$ ed. London, Chapman and Hall, $361 \mathrm{p}$.

Bromley, R.G. \& Asgaard, U. 1979. Triassic freshwater ichnocoenosis from Carlsberg Fjord, East Greenland. Palaeogeography, Palaeoclimatology, Palaeoecology, 28:39-80. doi.org/10.1016/00310182(79)90112-3

Bromley, R.G.; Uchman, A.; Gregory, M. \& Martin, A.J. 2003. Hillichnus lobosensis igen. et isp. nov., a complex trace fossil produced by tellinacean bivalves, Paleocene, Monterey, California, U.S.A. Palaeogeography, Palaeoclimatology, Palaeoecology, 192:157-186. doi.org/10.1016/S0031-0182(02)00684-3

Buatois, L.A. \& Mángano, M.G. 1993. Trace fossils from a Carboniferous turbiditic lake: implications for the recognition of additional nonmarine ichnofacies. Ichnos, 2:237-258. doi. org/10.1080/10420949309380098

Buatois, L.A. \& Mángano, M.G. 1995. The paleoenvironmental and paleoecological significance of the lacustrine Mermia Ichnofacies: an archetypical subaqueous nonmarine trace fossil assemblage. Ichnos, 4:151-161. doi.org/10.1080/10420949509380122

Buatois, L.A. \& Mángano, M.G. 2002. Trace fossils from Carboniferous floodplain deposits in western Argentina: implications for ichnofacies models of continental environments. Palaeogeography, Palaeoclimatology, Palaeoecology, 183:71-86. doi.org/10.1016/S0031-0182(01)00459-X

Buatois, L.A. \& Mángano, M.G. 2003. Early colonization of the deep sea: ichnologic evidence of deep-marine benthic ecology from the Early Cambrian of northwest Argentina. Palaios, 18:572-581. doi. org/10.1669/0883-1351(2003)018<0572:ECOTDS > 2.0.CO;2

Buatois, L.A. \& Mángano, M.G. 2004. Animal-substrate interactions in freshwater environments: applications of ichnology in facies and sequence stratigraphic analysis of fluvio-lacustrine successions. In: D. McIlroy (ed.) The application of ichnology to palaeoenvironmental and stratigraphic analysis, The Geological Society of London, Special Publication 228, p. 157-178.

Buatois, L.A. \& Mángano, M.G. 2007. Invertebrate ichnology of continental Freshwater environments. In: W. Miller, III (ed.) Trace fossils concepts, problems, prospects, Elsevier, p. 285-323.

Buatois, L.A.; Gingras, M.K.; MacEachern, J.A.; Mángano, M.G.; Zonneveld, J.P.; Pemberton, S.G.; Netto, R.G. \& Martin, A. 2005. Colonization of brackish-water systems through time: evidence from the trace-fossil record. Palaios, 20:321-347. doi. org/10.2110/palo.2004.p04-32

Buatois, L.A.; Jalfin, G. \& Aceñolaza, F.G. 1997. Permian nonmarine invertebrate trace fossils from Southern Patagonia, Argentina: ichnologic signatures of substrate consolidation and colonization sequences. Journal of Paleontology, 71:323-336.
Buatois, L.A.; Mángano, M.G. \& Aceñolaza, F.G. 2002. Trazas Fósiles: señales de comportamiento en el registro estratigráfico. Chubut, Arsa Gráfica, Edición Especial MEF 2, 382 p.

Buatois, L.A.; Mángano, M.G.; Brussa, E.D.; Benedetto, J.L. \& Pompei, J.F. 2009. The changing face of the deep: colonization of the Early Ordovician deep-sea floor, Puna, northwest Argentina. Palaeogeography, Palaeoclimatology, Palaeoecology, 280:291-299. doi.org/10.1016/j.palaeo.2009.06.014

Buatois, L.A.; Mángano, M.G.; Maples, C.G. \& Lanier, W.P. 1998. Taxonomic reassessment of the ichnogenus Beaconichnus and additional examples from the Carboniferous of Kansas, USA. Ichnos, 5:287-302. doi.org/10.1080/10420949809386427

Buatois, L.A.; Netto, R.G. \& Mángano, M.G. 2007. Ichnology of Permian marginal- to shallow-marine coal-bearing successions: Rio Bonito and Palermo Formations, Paraná Basin, Brazil. In: J.A. MacEachern; L.K. Bann; M.K. Gingras \& S.G. Pemberton (eds.) Applied ichnology, SEPM, Short Course Notes 52, p. 167-177.

Buatois, L.A.; Santiago, N.; Parra, K. \& Steel, R. 2008. Animal-substrate interactions in an Early Miocene wave-dominated tropical delta: delineating environmental stresses and depositional dynamics (Tácata Field, Eastern Venezuela). Journal of Sedimentary Research, 78:458-479. doi.org/10.2110/jsr.2008.053

Carmona, N.B.; Buatois, L.A. \& Mángano, M.G. 2004. The trace fossil record of burrowing decapod crustaceans: evaluating evolutionary radiations and behavioural convergence. Fossils and Strata, 51:141-153.

Carmona, N.B.; Buatois, L.A.; Ponce, J.J. \& Mángano, M.G. 2009. Ichnology and sedimentology of a tide-influenced delta, Lower Miocene Chenque Formation, Patagonia, Argentina: trace-fossil distribution and response to environmental stresses. Palaeogeography, Palaeoclimatology, Palaeoecology, 273:75-86. doi.org/10.1016/j.palaeo.2008.12.003

Chakraborty, A. \& Bhattacharya, H.N. 2005. Ichnology of a Late Paleozoic (Permo-Carboniferous) glaciomarine deltaic environment, Talchir Formation, Saharjuri Basin, India. Ichnos, 12:31-45. doi.org/10.1080/10420940590914480

Chamberlain, C.K. 1975. Recent lebensspuren in nonmarine aquatic sediments. In: R.W. Frey (ed.) The study of trace fossils, Springer-Verlag, p. 431-458.

Coates, L. \& MacEachern, J.A. 2007. The ichnological signatures of river- and wave-dominated delta complexes: differentiating deltaic and non-deltaic shallow marine successions, Lower Cretaceous Viking Formation and Upper Cretaceous Dunvegan Formation, west-central Alberta. In: J.A. MacEachern, L.K. Bann, M.K. Gingras \& S.G. Pemberton (eds.) Applied ichnology, SEPM, Short Course Notes 52, p. 227-254.

Corner, G.D. \& Fjalstadt, A. 1993. Spreite trace fossil (Teichichnus) in a raised Holocene fjord-delta, Breidvikeidt, Norway. Ichnos, 2:155-164. doi.org/10.1080/10420949309380085

Crimes, T.P. \& Crossley, J.D. 1991. A diverse ichnofauna from Silurian flysch of the Aberystwyth Grits Formation, Wales. Geological Journal, 26:27-64. doi.org/10.1002/gj.3350260104

Crimes, T.P.; Hidalgo, J.F.C. \& Poiré, D.G. 1992. Trace fossils from Arenig flysh sediments of Eire and their bearing on the early colonisation of the deep seas. Ichnos, 2:61-77. doi. org/10.1080/10420949209380076

Dam, G. 1990. Taxonomy of trace fossils from the shallow marine Lower Jurassic Neill Klinter Formation, East Greenland. Bulletin of the Geologic Society Denmark, 38:119-144.

Eagar, R.M.C.; Baines, J.G.; Collinson, J.D.; Hardy, P.G.; Okolo, S.A. \& Pollard, J.E. 1985. Trace fossil assemblages and their occurrence in Silesian (Mid-Carboniferous) deltaic sediments 
of the Central Pennine Basin - England. In: H.A. Curran (ed.) Biogenic structures: their use in interpreting depositional Environments, SEPM Special Publication 35, p. 99-150.

Ekdale, A.A. 1992. Mudckraking and mudslinging: the joys of deposit-feeding. In: C.G. Maples \& R.R. West (eds.) Trace fossils, Paleontological Society, Short Courses in Paleontology 5, p. 145-171.

Ekdale, A.A. \& Bromley, R.G. 2001. A day and a night in the life of a cleft-foot clam: Protovirgularia-Lockeia-Lophoctenium. Lethaia, 34:119-124. doi.org/10.1080/00241160152418410

Ekdale, A.A. \& Bromley, R.G. 2003. Paleoethologic interpretation of complex Thalassinoides in shallow-marine limestones, Lower Ordovician, southern Sweden. Palaeogeography, Palaeoclimatology, Palaeoecology, 192:221-227. doi.org/10.1016/ S0031-0182(02)00686-7

Ekdale, A.A. \& Lamond, R.E. 2003. Behavioral cladistics of trace fossils: evolution of derived trace-making skills. Palaeogeography, Palaeoclimatology, Palaeoecology, 192:335-343. doi.org/10.1016/ S0031-0182(02)00691-0

Figueiredo Filho, P.M. 1972. A faciologia do Grupo Passa Dois no Rio Grande do Sul. Revista Brasileira de Geociências, 2:216-35.

Fillion, D. \& Pickerill, R.K. 1984. On Arthraria antiquata Billings, 1972 and its relationship to Diplocraterion Torell, 1870 and Bifungites Desio, 1940. Journal of Paleontology, 58:683-696.

Frey, R.W. 1990. Trace fossils and hummocky cross-stratification, Upper Cretaceous of Utah. Palaios, 5:203-218. doi. org/10.2307/3514939

Frey, R.W. \& Howard, J.D. 1985. Trace fossils from the Panter Member, Star Point Formation (Upper Cretaceous), Coal Creek Canyon, Utah. Journal of Paleontology, 59:370-404.

Frey, R.W.; Pemberton, S.G. \& Saunders, T.D.A. 1990. Ichnofacies and bathymetry: a passive relationship. Journal of Paleontology, 64:155-158.

Gama Jr., E. 1979. Sedimentação do Grupo Passa Dois (inclusive Formação Irati): um modelo geomórfico. Revista Brasileira de Geociências, 9:1-16.

$\mathrm{Fu}$, S. 1991. Funktion, Verhalten und Einteilung fucoider und lophoctenoider Lebensspuren. Courier Forschungsinstitut Senckenberg, 135:1-79.

Gani, M.R.; Bhattacharya, J.P. \& MacEachern, J.A., 2007. Using ichnology to determine relative influence of waves, storms, tides and rivers in deltaic deposits: examples from Cretaceous delta complexes in the Western Interior Seaway, Wyoming - Utah, USA. In: J.A. MacEachern; L.K. Bann; M.K. Gingras \& S.G. Pemberton (eds.) Applied ichnology, SEPM, Short Course Notes 52, p.209-225.

Gibert, J.M. de \& Ekdale, A.A. 2002. Ichnology of a restricted epicontinental sea, Arapien Shale, Middle Jurassic, Utah, USA. Palaeogeography, Palaeoclimatology, Palaeoecology, 183:275-286. doi.org/10.1016/S0031-0182(01)00491-6

Gibert, J.M. de; Frenegal-Martínez, M.A.; Buatois, L.A. \& Mángano, M.G. 2000. Trace fossils and their palaeoecological significance in Lower Cretaceous lacustrine conservation deposits, El Montsec, Spain. Palaeogeography, Palaeoclimatology, Palaeoecology, 156:89-101. doi.org/10.1016/S0031-0182(99)00133-9

Gingras, M.K.; Bann, K.L.; MacEachern, J.A. \& Pemberton, S.G. 2007. A conceptual framework for the application of trace fossils. In: J.A. MacEachern; L.K. Bann; M.K. Gingras \& S.G. Pemberton (eds.) Applied ichnology, SEPM, Short Course Notes 52, p.1-26.

Goldring, R.; Pollard, J.E. \& Radley, J.D. 2005. Trace fossils and pseudofossils from the Wealden strata (non-marine Lower Cretaceous) of southern England. Cretaceous Research, 26:665-685. doi.org/10.1016/j.cretres.2005.03.001
Gradzinski, R. \& Uchman, A. 1994. Trace fossils from interdune deposits - an example from the Lower Triassic Aeolian Tumlin Sandstone, central Poland. Palaeogeography, Palaeoclimatology, Palaeoecology, 108:121-138. doi.org/10.1016/0031-0182(94)90025-6

Han, Y. \& Pickerill, R.K. 1995. Taxonomic revision of the ichnogenus Helminthopsis Heer 1877 with a statistical analysis of selected ichnospecies. Ichnos, 4:83-118. doi. org/10.1080/10420949509380118

Häntzschel, W. 1975. Treatise on Invertebrate Paleontology. Part W, Miscellanea, Suplement 1, Trace fossils and problematica. Kansas, University of Kansas and Geological Society of America, 269 p.

Hofmann, H.J.; Cecile, M.P. \& Lane, L.S. 1994. New occurrences of Oldhamia and other traces in the Cambrian of the Yukon and Ellesmere Island, arctic Canada. Canadian Journal of Earth Sciences, 31:767-782. doi.org/10.1139/e94-070

Johnson, E.W.; Briggs, D.E.G.; Suthren, R.J.; Wright, J.L. \& Tunnicliff, S.P. 1994. Non-marine arthropod traces from the subaereal Ordovician Borrowdale Volcanic Group, English lake District. Geological Magazine, 131:395-406. doi.org/10.1017/ S0016756800011146

Karaszewski, W. 1971. Some fossil traces from the lower Liassic of the Holy Cross Mts., Central Poland. Académie Polonaise des Science, Bulletin, Sèrie Sciences de la Terre, 19:101-105.

Keighley, D.G. \& Pickerill, R.K. 1995. The ichnotaxa Palaeophycus and Planolites: historical perspectives and recommendations. Ichnos, 3:301-309. doi.org/10.1080/10420949509386400

Keighley, D.G. \& Pickerill, R.K. 1996. Small Cruziana, Rusophycus, and related ichnotaxa from eastern Canada: the nomenclatural debate and systematic ichnology. Ichnos, 4:261-285. doi. org/10.1080/10420949609380136

Keighley, D.G. \& Pickerill, R.K. 1997. Systematic ichnology of the Mabou and Cumberland Groups (Carboniferous) of western Cape Breton Island, eastern Canada, 1: Burrows, pits, trails, and coprolites. Atlantic Geology, 33:181-215.

Keighley, D.G. \& Pickerill, R.K. 2003. Ichnocoenoses from the Carboniferous of eastern Canada and their implications for the recognition of ichnofacies in nonmarine strata. Atlantic Geology, 39:1-22.

Kim, J.Y.; Kim, K.-S. \& Pickerill, R.K. 2002. Cretaceous nonmarine trace fossils from the Hasandong and Jinju formations of the Namhae area, Kyongsangnamdo, Southeast Korea. Ichnos, 9:41-60. doi.org/10.1080/10420940216414

Klein, C.; Leipnitz, I.I. \& Nowatzki, C.H. 1999. Fácies sedimentares e observações bioestratinômicas das concentrações fossíliferas da Formação Teresina na região de Tiaraju, RS, Brasil. Acta Geologica Leopoldensia, 49:75-92.

Krapovickas, V.; Ciccioli, P.L.; Mángano, M.G.; Marsicano, C.A. \& Limarino, C.O. 2009. Paleobiology and paleoecology of an arid-semiarid Miocene South American ichnofauna in anastomosed fluvial deposits. Palaeogeography, Palaeoclimatology, Palaeoecology, 284:129-152. doi.org/10.1016/j.palaeo.2009.09.015

Lavina, E.L. 1991. Geologia sedimentar e paleogeografia do Neopermiano e Eotriássico (Intervalo Kazaniano-Scythiano) da Bacia do Paraná. Programa de Pós-Graduação em Geociências, Universidade Federal do Rio Grande do Sul, Doctorate thesis, 333 p.

Lermen, R.E. 2006. Assinaturas icnológicas em depósitos glaciogênicos do Grupo Itararé no RS. Programa de Pós-Graduação em Geologia, Universidade Vale do Rio dos Sinos, M.Sc. thesis, $84 \mathrm{p}$.

Leszczyński, S. 2004. Bioturbation structures of the Kropivnik Fucoid Marls (Campanian-lower Maastrichtian) of the Huwniki- 
Rybotycze area (Polish Carpathians). Geological Quarterly, 48:35-60.

Leszczynski, S.; Uchman, A. \& Bromley, R.G. 1996. Trace fossils indicating bottom aeration changes: Folusz Limestone, Oligocene, Outer Carpathians, Poland. Palaeogeography, Palaeoclimatology, Palaeoecology, 121:79-87. doi.org/10.1016/0031-0182(95)00052-6

Lima, J.H.D. 2010. Icnologia de depósitos marinhos regressivos: o exemplo da Formação Teresina (Permiano, bacia do Paraná) no Rio Grande do Sul. Programa de Pós-Graduação em Geologia, Universidade Vale do Rio dos Sinos, M.Sc. thesis, 102 p.

Lindholm, R.M. \& Casey, J.F. 1990. The distribution and possible biostratigraphic significance of the ichnogenus Oldhamia in the shales of the Blow Me Down Brook Formation, western Newfoundland. Canadian Journal of Earth Sciences, 27:1270-1287. doi.org/10.1139/e90-137

MacEachern, J.A.; Bann, K.L.; Bhattacharya, J.P. \& Howell, C.D. 2005. Ichnology of deltas, organism responses to the dynamic interplay of rivers, waves, storms, and tides. In: L. Giosan \& J.P. Bhattacharya (eds.) River Deltas: Concepts, Models and Examples, SEPM, Special Publication 83, p. 49-85.

MacEachern, J.A.; Pemberton, S.G., Bann, K.L. \& Gingras, M.K. 2007. Departures from the archetypal ichnofacies: effective recognition of physic-chemical stresses in the rock record. In: J.A. MacEachern; L.K. Bann; M.K. Gingras \& S.G. Pemberton (eds.) Applied Ichnology, SEPM, Short Course Notes 52, p. 65-93.

MacNaughton, R.B. 2007. The application of trace fossils to bioestratigraphy. In: W. Miller, III (ed.) Trace fossils concepts, problems, prospects, Geology Department Humboldt State University, p. 135-148.

Macsotay, O. 1967. Huellas problemáticas y su valor paleoecológico en Venezuela. GEOS, 16:7-79.

Mángano, M.G.; Buatois, L.A. \& Claps, G.L. 1996. Grazing trails formed by soldier fly larvae (Diptera: Stratiomyidae) and their paleoenvironmental and paleoecological implications for the fossil record. Ichnos, 4:163-167. doi.org/10.1080/10420949609380124

Mángano, M.G.; Buatois, L.A.; West, R.R. \& Maples, C.G. 1998. Contrasting behavioral and feeding strategies recorded by tidal-flat bivalve trace fossils from the Upper Carboniferous of Eastern Kansas. Palaios, 13:335-351. doi.org/10.2307/3515322

Maples, C.G. \& Suttner, L.J. 1990. Trace fossils and marinenonmarine cyclicity in the Fountain Formation (Pennsylvanian: Morrowan/Atokan) near Manitou Springs, Colorado. Journal of Paleontology, 64:859-880.

Martin, K.D. 2004. A re-evaluation of the relationship between trace fossils and dysoxia. In: D. McIlroy (ed.) The application of ichnology to palaeoenvironmental and stratigraphic analysis, The Geological Society of London, Special Publication 228, p. 141-156.

McIlroy, D. 2004. Ichnofabrics and sedimentary facies of a tidedominated delta: Jurassic Ile Formation of Kristin Field, Haltenbanken, Offshore Mid-Norway. In: D. McIlroy (ed.) The application of ichnology to palaeoenvironmental and stratigraphic analysis, The Geological Society of London, Special Publication 228, p. 237-272.

McIlroy, D. 2007. Ichnology of a macrotidal tide-dominated deltaic depositional system: Lajas Formation, Neuquén Province, Argentina. In: R.G. Bromley; L.A. Buatois; M.G. Mángano; J.F. Genise \& R.N. Melchor (eds.) Sediment-organism interactions; a multifaceted ichnology, SEPM Special Publication 88, p.195-211.

Melchor, R.N. 2004. Trace fossil distribution in lacustrine deltas: examples from the Triassic rift lakes of the Ischigualasto-Villa Union basin, Argentina. In: D. McIlroy (ed.) The application of ichnology to palaeoenvironmental and stratigraphic analysis, The Geological Society of London, Special Publication 228, p. 335-354.

Melchor, R.N.; Bellosi, E. \& Genise, J.F. 2003. Invertebrate and vertebrate trace fossils from a lacustrine delta: the Los Rastros Formation, Ischigualasto Provincial Park, San Juan, Argentina. Publicación Especial de la Asociación Palaeontológica Argentina, 9:17-33.

Milani, E.J. 1997. Evolução tectono-estratigráfica da bacia do Paraná e seu relacionamento com a geodinâmica fanerozóica do Gondwana Sul-Ocidental. Programa de Pós-Graduação em Geociências, Universidade Federal do Rio Grande do Sul, Doctorate thesis, $228 \mathrm{p}$.

Milani, E.J.; Melo, J.H.G.; Souza, P.A.; Fernandes, L.A. \& França, A.B. 2007. Bacia do Paraná. Boletim de Geociências da PETROBRAS, 15:265-287.

Miller III, W. 2011. A stroll in the forest of the fucoids: Status of Melatercichnus burkei Miller, 1991, the doctrine of ichnotaxonomic conservatism and the behavioral ecology of trace fossil variation. Palaeogeography, Palaeoclimatology, Palaeoecology, 307:109-116. doi.org/10.1016/j.palaeo.2011.05.002

Miller III, W. \& Aalto, K.R. 1998. Anatomy of a complex trace fossil: Phymatoderma from Pliocene bathyal mudstone, northwestern Ecuador. Paleontological Research, 2:266-274.

Miller III, W. \& Vokes, E.H. 1998. Large Phymatoderma in Pliocene slope deposits, northwestern Ecuador: associated ichnofauna, fabrication, and behavioral ecology. Ichnos, 6:23-45. doi. org/10.1080/10420949809386437

Myrow, P.M. 1995. Thalassinoides and the enigma of Early Paleozoic open-framework burrow systems. Palaios, 10:58-74. doi. org $/ 10.2307 / 3515007$

Netto, R.G. 1988. Paleoicnologia dos sedimentitos basais da Formação Rio do Rasto no Estado do Rio Grande do Sul. Programa de Pós-Graduação em Geociências, Universidade Federal do Rio Grande do Sul, M.Sc. thesis, 92 p.

Netto, R.G. 1992. Paleoecology of ichnocoenoses in the Cruziana Ichnofacies, Serrinha Member, Rio do Rasto Formation, (Upper Permian) from the Parana Basin, Rio Grande do Sul, Brazil. Acta Geologica Leopoldensia, 36:67-82.

Netto, R.G. 2001. Icnologia e estratigrafia de seqüências. In: H.J.P. Severiano Ribeiro (ed.) Estratigrafia de seqüencias fundamentos e aplicações, Ed. UNISINOS, p. 219-259.

Netto, R.G.; Balistieri, P.R.M.N.; Lavina, E.L.C. \& Silveira, D.M. 2009. Ichnological signatures of shallow freshwater lakes in the glacial Itararé Group (Mafra Formation, Upper Carboniferous-Lower Permian of Paraná Basin, S Brazil). Palaeogeography, Palaeoclimatology, Palaeoecology, 272:240255. doi.org/10.1016/j.palaeo.2008.10.028

Noffke, N.; Gerdes, G.; Klenke, T. \& Krumbein, W.E. 2001. Microbially induced sedimentary structures - a new category within the classification of primary sedimentary structures. Journal of Sedimentary Research, 71:649-656. doi.org/10.1306/2DC4095D0E47-11D7-8643000102C1865D

Nogueira, M.S. \& Netto, R.G. 2001a. A presença de Cruziana nos sedimentos da Formação Rio do Sul (Grupo Itararé, Permocarbonífero da bacia do Paraná) na pedreira Itaú-Itaúna, Santa Catarina, Brasil. Acta Geologica Leopoldensia, 52/53:387-396.

Nogueira, M.S. \& Netto, R.G. 2001b. Icnofauna da Formação Rio do Sul (Grupo Itararé, Permiano da bacia do Paraná) na pedreira Itaú-Itaúna, Santa Catarina, Brasil. Acta Geologica Leopoldensia, 52/53:397-406.

Pemberton, S.G. \& Frey, R.W. 1982. Trace fossil nomenclature and 
the Planolites - Palaeophycus dilemma. Journal of Paleontology, 56:843-881.

Pemberton, S.G.; Frey, R.W. \& Bromley, R.G. 1988. The ichnotaxonomy of Conostichus and other plug-shaped ichnofossils. Canadian Journal of Earth Sciences, 25:886-892. doi.org/10.1139/e88-085

Pemberton, S.G.; Frey, R.W. \& Walker, R.G. 1984. Probable lobster burrows in the Cardium Formation (Upper Cretaceous) of southern Alberta, Canada, and comments on modern burrowing decapods. Journal of Paleontology, 58:1422-1435.

Pemberton, S.G.; MacEachern, J.A. \& Frey, R.W. 1992. Trace fossil facies models: environmental and allostratigraphic significance. In: R.G. Walker \& N.P. James (eds.) Facies models: response to sea level changes. Geological Association of Canada, p. 47-72.

Pemberton, S.G.; MacEarchern, J.A. \& Saunders, T. 2004. Stratigraphic applications of substrate-specific ichnofacies: delineating discontinuities in the rock record. In: D. McIlroy (ed.) The application of ichnology to palaeoenvironmental and stratigraphic analysis, Special Publication Geological Society of London 228, p. 29-62.

Pemberton, S.G.; Spila, M.; Pulham, A.J.; Saunders, T.; Robbins, D. \& Sinclair, I.K. 2001. Ichnology and sedimentology of shallow to marginal marine systems. Calgary, Geological Association of Canada, Short Course 15, 343 p.

Pemberton, S.G. \& Wightman, D.M. 1992. Ichnological characteristics of brackish water deposits. In: Pemberton, S.G. (ed.) Applications of Ichnology to Petroleum Exploration - a core workshop, SEPM, Core Workshop 17, p.141-167.

Pieńkowski, G. 2008. Jurassic of the Holy Cross Mountains. In: A. Uchman (ed.) Types of invertebrate trace fossils from Poland: an illustrated catalogue, Polish Geological Institute, p. 20-23.

Pollard, J.E. 1985. Isopodichnus, related arthropod trace fossils and notostracans from Triassic fluvial sediment. Transactions of the Royal Society of Edinburgh, Earth Sciences, 76:273 285.

Rieth, A. 1932. Neue Funde spongeliomorpher Fucoiden aus dem Jura Schwabens. Geologische und Palaeontologische Abhandlungen, 19:257-294.

Rodríguez-Tovar, F.J.; Puga-Bernabéu, A. \& Buatois, L.A. 2008. Large burrow systems in marine Miocene deposits of the Betic Cordillera (Southeast Spain). Palaeogeography, Palaeoclimatology, Palaeoecology, 268:19-25. doi.org/10.1016/j.palaeo.2008.07.022

Rodríguez-Tovar, F.J.; Uchman, A.; Payros, A.; Orue-Etxebarria, X.; Apellaniz, E. \& Molina, E. 2010. Sea-level dynamics and palaeoecological factors affecting trace fossil distribution in Eocene turbiditic deposits (Gorrondatxe section, N Spain). Palaeogeography, Palaeoclimatology, Palaeoecology, 285:50-65. doi.org/10.1016/j.palaeo.2009.10.022

Rohn, R. 1989. Grupo Passa Dois. In: CONGRESSO BRASILEIRO DE PALEONTOLOGIA, 11, 1989. Anais, Curitiba, Sociedade Brasileira de Paleontologia, 5:34-42.

Rossetti, D.F. \& Netto, R.G. 2006. First evidence of marine influence in the Cretaceous of the Amazonas Basin, Brazil. Cretaceous Research, 27:513-528. doi.org/10.1016/j.cretres.2005.10.014

Sarkar, S.; Ghosh, S.K. \& Chakraborty, C. 2009. Ichnology of a Late Palaeozoic ice-marginal shallow marine succession: Talchir Formation, Satpura Gondwana Basin, central India. Palaeogeography, Palaeoclimatology, Palaeoecology, 283:28-45. doi.org/10.1016/j.palaeo.2009.09.001

Savrda, C.E. 2007. Trace fossils and marine benthic oxygenation. In: W. Miller, III (ed.) Trace fossils concepts, problems, prospects, Geology Department Humboldt State University, p. 149-158.

Savrda, C.E. \& Nanson, L.L. 2003. Ichnology of fair-weather and storm deposits in an Upper Cretaceous estuary (Eutaw Formation, western
Georgia, USA). Palaeogeography, Palaeoclimatology, Palaeoecology, 202:67-83. doi.org/10.1016/S0031-0182(03)00628-X

Schlirf, M.; Uchman, A. \& Kummel, M. 2001. Upper Triassic (Keuper) non-marine trace fossils from the Hagberge area (Franconia, south-eastern Germany). Paläontologische Zeitschrift, 75:71-96.

Schneider, R.L.; Mülmann, H.; Tommasi, E.; Medeiros, R.A.; Daemon, R.F. \& Nogueira, A.A. 1974. Revisão estratigráfica da Bacia do Paraná. In: CONGRESSO BRASILEIRO DE GEOLOGIA, 28, 1974. Anais, Porto Alegre, Sociedade Brasileira de Geologia, 1:41-65.

Scott, J.J.; Renaut, R.W.; Buatois, L.A. \& Owen R.B. 2009. Biogenic structures in exhumed surfaces around saline lakes: an example from Lake Bogoria, Kenya Rift Valley. Palaeogeography, Palaeoclimatology, Palaeoecology, 272:176198. doi.org/10.1016/j.palaeo.2008.12.002

Seilacher, A. 1964. Biogenic sedimentary structures. In: J. Imbrie \& N.D. Newel (eds.) Approaches to Paleoecology, John Wiley \& Sons, p. 296-316.

Seilacher, A. 2007. Trace fossil analysis. Heidelberg, Springer-Verlag, $226 \mathrm{p}$.

Seilacher, A. 2008. Biomats, biofilms, and bioglue as preservational agents for arthropod trackways. Palaeogeography, Palaeoclimatology, Palaeoecology, 270:252-257. doi.org/10.1016/j.palaeo.2008.07.011

Seilacher, A.; Buatois, L.A. \& Mángano, M.G. 2005. Trace fossils in the Ediacaran-Cambrian transition: behavioral diversification, ecological turnover and environmental shift. Palaeogeography, Palaeoclimatology, Palaeoecology, 227:323-356. doi.org/10.1016/j. palaeo.2005.06.003

Seilacher, A. \& Seilacher, E. 1994. Bivalvian trace fossils: a lesson from actuopaleontology. Courier Forschungsinstitut Institut Senckenberg, 169:5-15.

Stanton, R. J. \& Dodd, J. R. 1984. Teichichnus pescaderoensis - new ichnospecies in the Neogene shelf and slope sediments, California. Facies, 11:219-228. doi.org/10.1007/BF02536911

Taylor, A.M. \& Goldring, R. 1993. Description and analysis of bioturbation and ichnofabric. Journal of the Geological Society of London, 150:141-148. doi.org/10.1144/gsjgs.150.1.0141

Turner, B.R.; Stanistreet, I.G. \& Whateley, M.K.G. 1981. Trace fossils and palaeoenvironments in the Ecca Group of the Nongoma Graben, northern Zuzuland, South Africa. Palaeogeography, Palaeoclimatology, Palaeoecology, 36:113-123.

Uchman, A. 1995. Taxonomy and palaeoecology of flysch trace fossils: the Marnoso arenacea formation and associated facies (Miocene, Northern Apennines, Italy). Beringeria, 15:3-115. doi.org/10.1016/0031-0182(81)90053-5

Uchman, A. 1998. Taxonomy and ethology of flysch trace fossils: revision of the Marian Książkiewicz collection and studies of complementary material. Annales Societatis Geologorum Poloniae, 68:105-218.

Uchman, A. 1999. Ichnology of the Rhenodanubian Flysch (Lower Cretaceous-Eocene) in Austria and Germany. Beringeria, 25:65-171.

Uchman, A. 2001. Eocene flysch trace fossils from the Hecho Group of the Pyrenees, northern Spain. Beringeria, 28:3-41.

Uchman, A.; Drygant, D; Paszkowski, M.; Porębski, S.J. \& Turnau, E. 2004. Early Devonian trace fossils in marine to non-marine redbeds in Podolia, Ukraine: palaeoenvironmental implications. Palaeogeography, Palaeoclimatology, Palaeoecology, 214:6783. doi.org/10.1016/j.palaeo.2004.07.022

Uchman, A. \& Gaździcki, A. 2010. Phymatoderma melvillensis isp. nov. and other trace fossils from the Cape Melville Formation (Lower Miocene) of King George Island, Antarctica. Polish Polar Research, 31:83-99. doi.org/10.4202/ppres.2010.06 
Uchman, A.; Hanken, N. \& Binns, R. 2005. Ordovician bathyal trace fossils from metasiliciclastics in Central Norway and their sedimentological and paleogeographical implications. Ichnos, 12:105-133. doi.org/10.1080/10420940590914534

Uchman, A.; Kazakauskas, V. \& Gaigalas, A. 2009. Trace fossils from Late Pleistocene varved lacustrine sediments in eastern Lithuania. Palaeogeography, Palaeoclimatology, Palaeoecology, 272:199-211. doi.org/10.1016/j.palaeo.2008.08.003

Uchman, A.; Mikuláš, R. \& Rindsberg, A.K. 2011. Mollusc trace fossils Ptychoplasma Fenton \& Fenton, 1937 and Oravaichnium
Plička \& Uhrová, 1990: their type material and ichnospecies. Geobios, 44:387-397. doi.org/10.1016/j.geobios.2010.08.001

Wetzel, A. \& Bromley, R.G. 1996. Re-evaluation of the ichnogenus Helminthopsis - a new look at type material. Palaeontology, 39:1-19.

Wildner, W.; Ramgrab, G.E.; Cunha Loopes, R. \& Iglesias, C.M.F. 2006. Mapa Geológico do Estado do Rio Grande do Sul. Escala 1:750000. CPRM, Serviço Geológico do Brasil. Porto Alegre, RS.

Received in August, 2011; accepted in December, 2011. 